\title{
Archaeological Survey in the South Caucasus (Samtskhe-Javakheti, Georgia)
}

Approaches, Methods and First Results

William Anderson, Jessie Birkett-Rees, Michelle Negus Cleary, Damjan Krsmanovic and Nikoloz Tskvitinidze

\section{OpenEdition}

\section{Journals}

Electronic version

URL: http://journals.openedition.org/anatoliaantiqua/283

DOI: 10.4000/anatoliaantiqua.283

\section{Publisher}

IFEA

\section{Printed version}

Date of publication: 1 January 2014

Number of pages: 11-33

ISBN: 9782362450136

ISSN: 1018-1946

\section{Electronic reference}

William Anderson, Jessie Birkett-Rees, Michelle Negus Cleary, Damjan Krsmanovic and Nikoloz Tskvitinidze, "Archaeological Survey in the South Caucasus (Samtskhe-Javakheti, Georgia) », Anatolia Antiqua [Online], XXII | 2014, Online since 11 December 2018, connection on 18 December 2020. URL http://journals.openedition.org/anatoliaantiqua/283 ; DOI : https://doi.org/10.4000/anatoliaantiqua 283 


\section{ANATOLIA ANTIQUA ESKI ANADOLU}

\section{XXII}

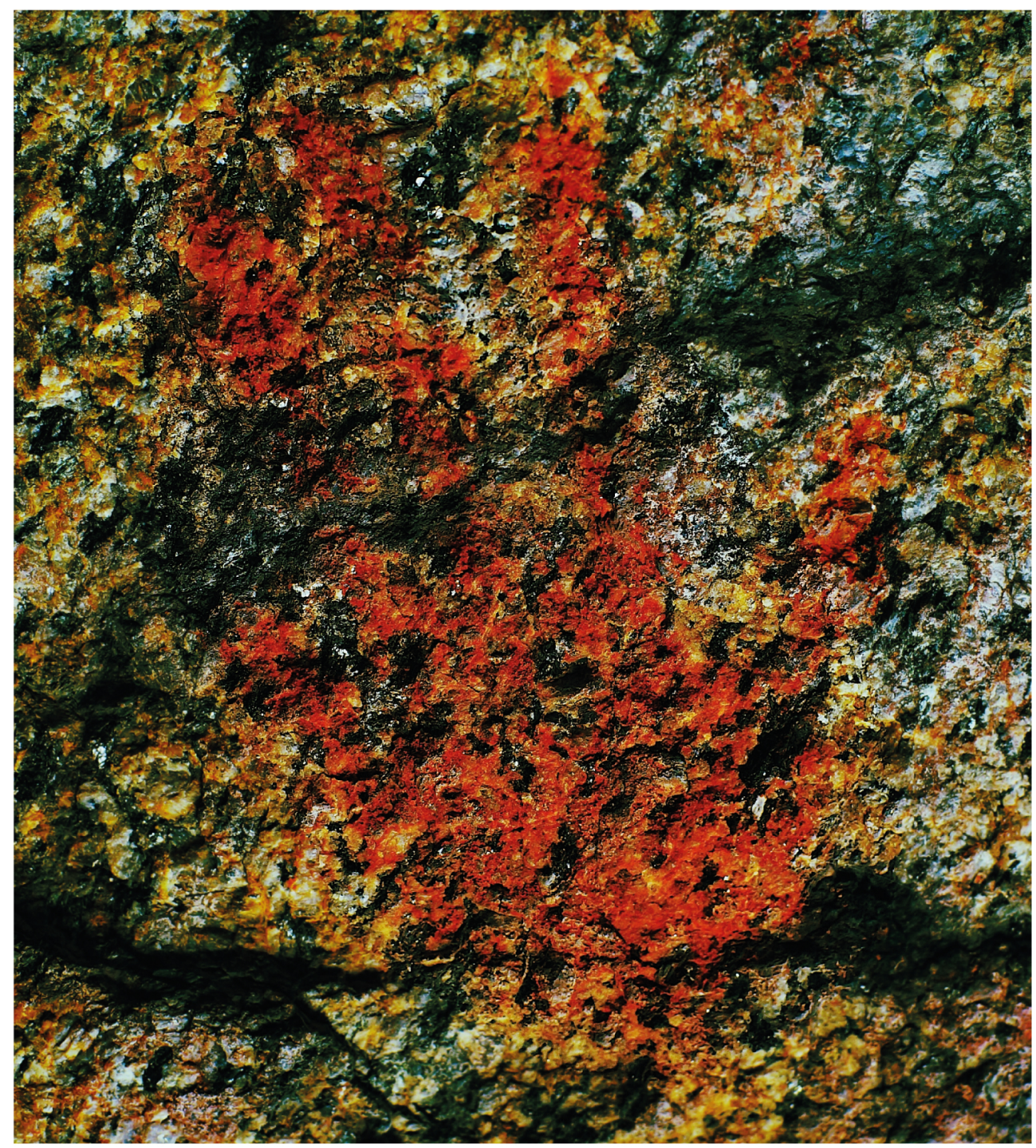

INSTITUT FRANÇAIS D'ETUDES ANATOLIENNES GEORGES-DUMEZIL CNRS USR 3131

DE BOCCARD 


\section{TABLE DES MATIERES}

Emma BAYSAL,

A preliminary typology for beads from the Neolithic and Chalcolithic levels of Barcın Höyük

William ANDERSON, Jessie BIRKETT-REES, Michelle NEGUS CLEARY,

Damjan KRSMANOVIC et Nikoloz TSKVITINIDZE,

Archaeological survey in the South Caucasus (Samtskhe-Javakheti, Georgia):

Approaches, methods and first results

Eda GÜNGÖR ALPER,

Hellenistic and Roman period ceramic finds from the Balatlar Church excavations in

Sinop between 2010-2012

Ergün LAFLI et Gülseren KAN ŞAHİN,

Hellenistic ceramics from Southwestern Paphlagonia

Oğuz TEKIN,

Weights of Lysimachea from the Tekirdağ Museum and various collections

Oğuz TEKIN,

Three weights of Lampsacus

Julie DALAISON et Fabrice DELRIEUX,

La cité de Néapolis-Néoclaudiopolis : histoire et pratiques monétaires

Martine ASSENAT et Antoine PEREZ,

Amida 4. Constance II et Amida

Sencan ALTINOLUK et Nilüfer ATAKAN,

Abrasax: A magical gem in the Istanbul Archaeological Museums

Bahadır DUMAN,

A group of local production Middle Byzantine period pottery from Tripolis:

'Micaceous White Painted Ware'

CHRONIQUES DES TRAVAUX ARCHEOLOGIQUES EN TURQUIE, 2014

Jean-Charles MORETTI,

avec la collaboration de Nicolas BRESCH, Isabel BONORA, Jean-Jacques MALMARY et

Olivier RISS,

Claros, le Temple d'Apollon : travaux réalisés en 2013

Suat ATEŞLIER,

On the excavations of the Zeus Temple of Alabanda 
Olivier HENRY,

avec Ayşe Güliz BİLGIN ALTINÖZ, Jesper BLID, Ömür Dünya ÇAKMAKLI, Andrew DUFTON, Agneta FRECCERO, Linda GOSNER, Ragnar HEDLUND, Pascal LEBOUTEILLER,

Vasilica LUNGU, Felipe ROJAS, Fredrik TOBIN, Baptiste VERGNAUD et

Andrew WATERS,

La mission Labraunda 2013 - Rapport préliminaire

Dominique BEYER, Isabelle CHALIER, Françoise KIRNER,

Françoise LAROCHE-TRAUNECKER et Aksel TIBBET,

Zeyve Höyük - Porsuk. Rapport préliminaire sur la campagne 2013

Çiğdem MANER,

Preliminary report on the first season of the Konya-Ereğli (KEYAR) survey 2013 


\section{William ANDERSON, Jessie BIRKETT-REES, Michelle NEGUS CLEARY, Damjan KRSMANOVIC and Nikoloz TSKVITINIDZE*}

\section{ARCHAEOLOGICAL SURVEY IN THE SOUTH CAUCASUS (SAMTSKHE-JAVAKHETI, GEORGIA): APPROACHES, METHODS AND FIRST RESULTS}

The Landscape Archaeology in Georgia Project (LAG) is a multi-period archaeological survey that operates within Samtskhe-Javakheti province, also known as Meskheti, in southern Georgia (Fig. 1) ${ }^{1}$. The region shares political borders with Turkey to the west and southwest and Armenia to the southeast. Its mountainous geography provides natural connections across these modern boundaries, linking the Kars and the Armenian highlands with southwest Georgia, each sharing a similar topography, elevation, ecology and hydrology. The Kura River (Mtkvari), which is within the study area, is a significant feature of the Caucasus region, rising in northeastern Turkey and crossing into Georgia where it cuts a deep course through the highlands before flowing out into the plain at Kashuri and continuing toward Azerbaijan and the Caspian Sea.

The LAG project aims to enrich understanding of the archaeological landscape of the southern Caucasus; to contribute to thematic debates on occupation of highland environments; and to investigate settlement patterns and material culture of the prehistoric, classical, medieval and modern past. Particular research themes we are concerned with entail movement and interactions at a local and regional scale. Whilst gathering accurate spatial data on archaeological features, a variety of methods and recording techniques are being tested that capture different scales and qualities of information, including systematic site recording and intensive surface artefact survey. Further, by documenting and assessing the condition of sites and features, the project makes a contribution to heritage management in present-day Georgia.
In this report, we outline the project's background, its methods, and its preliminary findings made during two seasons of fieldwork in 2012 and 2013. Surveyed areas are discussed in a series of sketches which address physical and archaeological aspects of distinctive localities, sites and features. These raise a number of research questions regarding the chronology and usage of the landscape, and its modification over the short and long term. By arranging our preliminary results according to location and context, our aim is to introduce the diversity and complexity of archaeological remains which will be the subject of more detailed thematic and chronological investigations in future seasons.

\section{BACKGROUND}

Often described as a crossroads between Asia and Europe, the geography of the southern Caucasus offers limited passages through the mountains, river valleys and high plateaus. The diverse topography and environment both restrict and facilitate movement and provide natural strongholds and rich resources. Located within the sphere of Mesopotamian cultural practices and networks during the Late Chalcolithic and Early Bronze Age periods; slightly beyond the Urartian Empire in the Iron Age; at the fringes of the Iberian and Colchian kingdoms during classical antiquity; and at the furthest reaches of Persian and Roman imperial territories, the study area appears to have been a borderland at several stages in its recent and distant past. This is not to say that the region is peripheral or marginal on account of its mountainous geography: its position formed a place

*) William Anderson, Classics and Archaeology, University of Melbourne; Jessie Birkett-Rees, Department of Archaeology, La Trobe University; Michelle Negus Cleary, Department of Archaeology, University of Sydney; Damjan Krsmanovic, School of Archaeology and Ancient History, University of Leicester; Nikoloz Tskvitinidze, Cultural Resources Exploration Center, Tbilisi.

1) Our team is indebted to Prof. David Lordkipanidze, General Director of the Georgian National Museum, for permission to work in the Samtskhe-Javakheti region, and to Dr. Kakha Kakhiani for support and collaboration. We are grateful to the Georgian-Australian Investigations in Archaeology (GAIA) project and Prof. Antonio Sagona and Dr. Claudia Sagona for hosting us in Zveli and Giorgi Bedianashvili for logistical help. Thanks are also owed to The University of Melbourne and La Trobe University Archaeology departments for access to DGPS and handheld GPS equipment. 


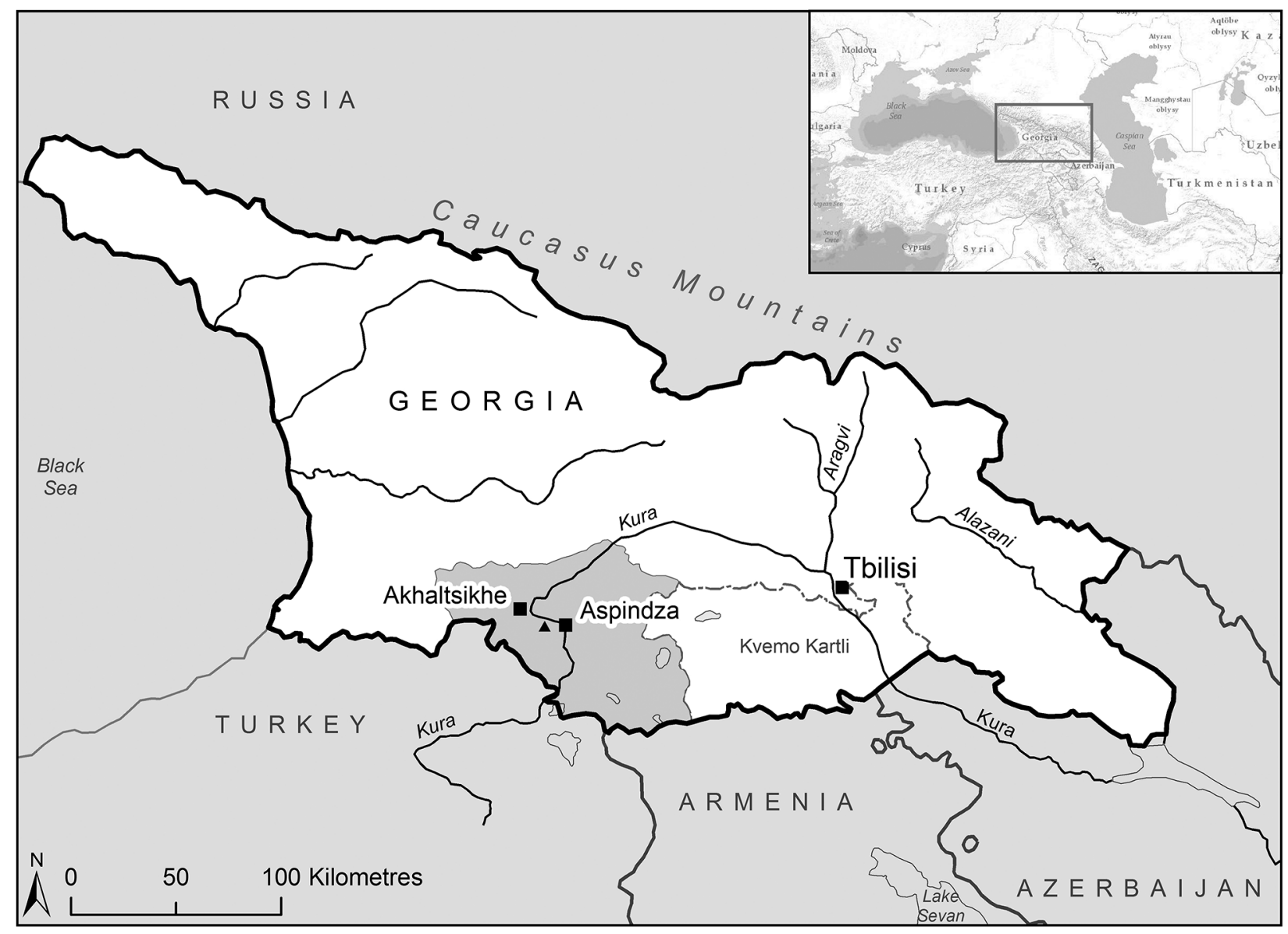

Samtskhe-Javakheti province $\Delta$ Zveli village

Major rivers

Fig. 1 : Map of Georgia and the southwest Caucasus region.

of cultural interaction, as part of both the ancient Near East and Eurasia, as well as being home to distinctive local cultural traditions ${ }^{2}$.

The region has historically maintained connections with Anatolia, Mesopotamia, the Black Sea and the Eurasian steppe. But as a militarised frontier during the Soviet period, local researchers' activities and international collaboration have been limited until recent years. Investigations undertaken in the 1950s-1980s form the basis of knowledge on the region's archaeology (Bedianashvili, in Kakhiani et al. 2013: 5-6). The principal source of information derives from the joint expedition of the Vardzia Museum-Reserve and the Tbilisi Pushkin Pedagogical Institute, led by T. Chubinishvili in 1953-55 (Chubinishvili et al. 1957), along with the work of O. Djaparidze and O. Gambashidze during the 1970s and 1980s (Djaparidze 1981; Gambashidze and Kvijinadze 1979; 1981; 1982; Gambashidze et al. 1980; 1984; 1985; 2004).

Investigations led by Chubinishvili sought to locate Palaeolithic remains in an area where none had been previously attested. Though the earliest finds from Chubinishvili's surveys were dated to the Chalcolithic period $^{3}$, the surveys were notable for documenting several kurgans - barrow burials of the Middle and Late Bronze Ages - as well as multilayered settlements in the Uraveli Gorge. Chubinishvili also excavated at Amiranis Gora, on the northeastern outskirts of Akhaltsikhe, which has become an important point of reference for the architecture, burial practices, material culture and metallurgy of the Early Bronze Age Kura-Araxes culture, also known as the Early Transcaucasian Culture (Palumbi 2008;

2) On ideas of borderlands in the Caucasus, see Smith and Rubinson 2003; Marro 2012.

3) Recent investigations have identified Acheulean stone tools from surface collections near Vale, west of Akhaltsikhe (Grigolia, in Baramidze and Pkhakadze 2007: 16-19). 
Kiguradze and Sagona 2003; Burney and Lang 1971; Chubinishvili 1963).

In the $1970 \mathrm{~s}$, the neighbouring province of Kvemo Kartli became a focus for specialists working on the elaborate kurgans belonging to the Trialeti culture of the Middle Bronze Age, on the Tsalka Plateau (Kuftin 1940). The distribution of kurgans was the motivation for research undertaken in the 1970s by O. Djaparidze whose initial focus was on the uplands surrounding Vardzia. Djaparidze identified large stone mounds typical of the Trialeti culture located alongside circular stone cromlechs, which he considered to be a local variation of the Trialeti burials (Djapadridze 1981). The northernmost distribution of these burials was observed near the village of Zveli (Dzveli). Further investigations in the mid1970 s and 1980s, directed by O. Gambashidze, identified groups of barrows, dating to the transitional Middle Bronze and Late Bronze Ages, and again exhibiting two different styles: stone mounds and stone cromlechs.

In recent years, there have been several rescue excavation projects in Samtskhe-Javakheti, notably work connected with construction of the Baku-Tbilisi-Ceyhan pipeline, which runs directly through the region (Gamkrelidze 2010). Excavated sites in the vicinity of LAG's study area include Roman-period graves at Klde (Gambashidze and Mindiashvili 2006), medieval settlement remains at Atskuri (Licheli et al. 2007) and Chorati, where there are classical and medieval graves and structures (Baramidze and Pkhakadze 2007). Excavations at Tiselis Seri, south of Borjomi, identified structures and burials that were dated to the second quarter of the $3^{\text {rd }}$ millennium B.C. and display attributes of the Kura-Araxes culture (Gogochuri and Orjonikidze 2007). Just across the border, in Ardahan province (Turkey), excavations at Sazpegler recovered detailed information on a late medieval settlement and its material culture (Tekinalp and Ekim 2005). Physical remains of the medieval period are conspicuous in our region, among them settlements and field systems, churches and fortifications, and the famous cave settlement at Vardzia, cut into the high cliffs along the Kura River gorge, $21 \mathrm{~km}$ south of Aspindza.

The construction of a separate gas pipeline between Akhaltsikhe and Aspindza resulted in the discovery of Bronze Age features along the upper slopes of a hill above the village of Chobareti (Kakhiani et al. 2013: 2). Following salvage excavations in 2009, the site has become the focus for an international excavation project as part of the Georgian-Australian Investigations in Archaeology
(GAIA), co-directed by Prof. Antonio Sagona (University of Melbourne) and Dr. Kakha Kakhiani (Georgian National Museum), which has identified Early Bronze Age buildings and burials and medieval remains (Kakhiani et al. 2013).

Previous archaeological fieldwork in the southern Georgian highlands has been intermittent, yet its results clearly indicate the potential of future research with an opportunity to integrate new results with the findings of past studies. The highland plateaus and mountain ranges which rise across southern Georgia, Armenia and northeastern Turkey form a complex setting in which to investigate longterm trends, processes and interactions between people and landscapes, as the ArAGATS Project in Armenia has demonstrated (Smith et al. 2009). There remains scope for a truly multi-period approach to the region's archaeological landscape which takes in material of the earlier and later historical, as well as prehistoric, periods. Furthermore, the LAG project addresses a region which is undergoing increasing modern development, including the installation of oil and gas pipelines and the current construction of a dam to the northeast of Aspindza. In the context of encroaching industrialisation, it is timely to record the region's archaeological heritage and to examine the coexistence of ancient and contemporary highland landscapes.

\section{METHODS}

Three basic field methods were used by the LAG Project during the 2013 season: extensive survey and site recording, systematic transect walking and intensive surface artefact survey.

The extensive survey aimed to locate and document archaeological features in order to assess the range and chronology of material in the study area. This approach was informed by satellite and aerial imagery, modern and historical maps, previous archaeological studies and knowledge offered by local people. Topographic maps produced under Soviet authorities in the 1980s contain detailed information on the local geography and also notate archaeological features - 'ruins' (razvaliny), 'burial mounds' (kurganov) and buildings such as churches (tserkov'). Another important source is the Register of Gürcistan Vilayet, an administrative document made by Ottoman authorities in A.D. 1595 following their takeover of the region in 1578 (Svanidze 1987: 331; Rayfield 2012: 181). In the 1950s, Georgian geographer A. Aslanikashvili drew a map that illustrates this information (Dzhikiya 1958). The map, which we have georeferenced and found to be reli- 
able, provides invaluable details on aspects of historical geography, including settlement locations and place names at the end of the $16^{\text {th }}$ century.

Alongside remote sensing reconnaissance and reference to written and spoken sources, two systematic survey techniques were implemented. First, blocks of land (transects) measuring $0.5-1.5 \mathrm{~km}$ in length and 100-200 $\mathrm{m}$ in width were surveyed systematically by the five person team ${ }^{4}$. Transects were chosen to capture information on different locations and topographies. The aim was to intersect with archaeological features to obtain a broad but systematic view of site distribution and types.

Second, intensive surface artefact survey investigated small areas of land, mostly formed by modern field boundaries, ranging in area from $750-10,000 \mathrm{~m}^{2}$. Intensive survey units (SUs) were chosen to give a representative sample of locations; the choice was also guided by the suitability of fields, especially favouring ploughed and cultivated land that offered good surface visibility. Where possible, two or more contiguous or nearby fields were surveyed. The aim was to obtain detailed information on the distribution and type of artefacts at concentrated points in the landscape.

Having chosen a field for intensive survey, the location, ground conditions and physical context (environment, views, landmarks) were recorded. Four to five walkers were spaced at $5 \mathrm{~m}$ or $10 \mathrm{~m}$ intervals, often along the line of ploughed furrows, placing flags to record the position of artefacts. These locations were then recorded individually using a DGPS $^{5}$, including the artefact material/type, and the artefacts were collected for analysis. GPS points were taken at the corners of each SU which were then drawn as polygons using aerial images in a Geographic Information System (GIS).

The three methods generated different qualities and scales of information. Extensive survey, including chance discoveries, located a wide range of places and features, from Bronze and Iron Age deposits to named medieval villages with standing structures. Systematic transect walking north of Kheoti, south of Chobareti and beside the Kura River detected sites that appear to date predominantly from the medieval period, most of which were previously unrecorded. The method's utility was shown by the number and range of features encountered, consisting of stone built villages and farm- steads, as well as walled field boundaries, terraces and roadways. These suggest a significant density of settlement in the medieval period, which is also strongly represented in the artefact collections from intensive survey.

Intensive survey proved an effective way of obtaining high resolution information on surface artefact distributions. The bulk of recorded artefacts consist of ceramic sherds $(96 \%)$; most other finds are lithics as well as a small number of glass and metal items. Information on the density, chronology and type of artefact scatters in different parts of the study area suggest the presence of past occupation areas where there are no above-ground structural remains. Although a number of factors may affect the density and type of artefacts present in the ploughsoil, certain artefact scatters are likely to reflect historical settlement and land use in particular locales. This is shown by consistency in the typochronology of finds from neighbouring SUs and variation across larger areas.

In the following sections, selected areas and recorded sites are reviewed. Described sites and features are summarised in Appendix 1, including chronology estimates, which are presented in Appen$\operatorname{dix} 2$.

\section{AN ARCHAEOLOGICAL LANDSCAPE: SURVEYED AREAS AND KEY SITES}

The field surveys in 2013 concentrated on the region between Akhaltsikhe in the west and Aspindza in the east, bounded by the Kura River in the North and extending into the highlands south of Zveli village (Fig. 2). The team was based at Zveli, and much of the work took place in the upland plains and stream valleys surrounding Zveli, Chobareti, and the neighbouring villages of Muskhi, Orgora and Sakudabeli. Beyond this area, visits were made to the valley floor and foothills along the Kura River and the highland pastures (yayla) South and Southeast of Zveli.

\section{Highlands and Lowlands}

One of the research agendas of the LAG project is the identification of archaeological features at different altitudes and in different environmental settings, which may be indicative of temporal trends in

4) The extensive survey was documented using hand-held Garmin GPSmap 60CSx units and a Trimble DGPS system (see note 5, below). The hand-held units have an accuracy range of 2.5-4 m.

5) A Trimble GeoXH rover unit and SPS770 base station receiver were used for survey, with correction via post-survey processing. The resulting data have an accuracy of $\pm 20 \mathrm{~cm}$. 


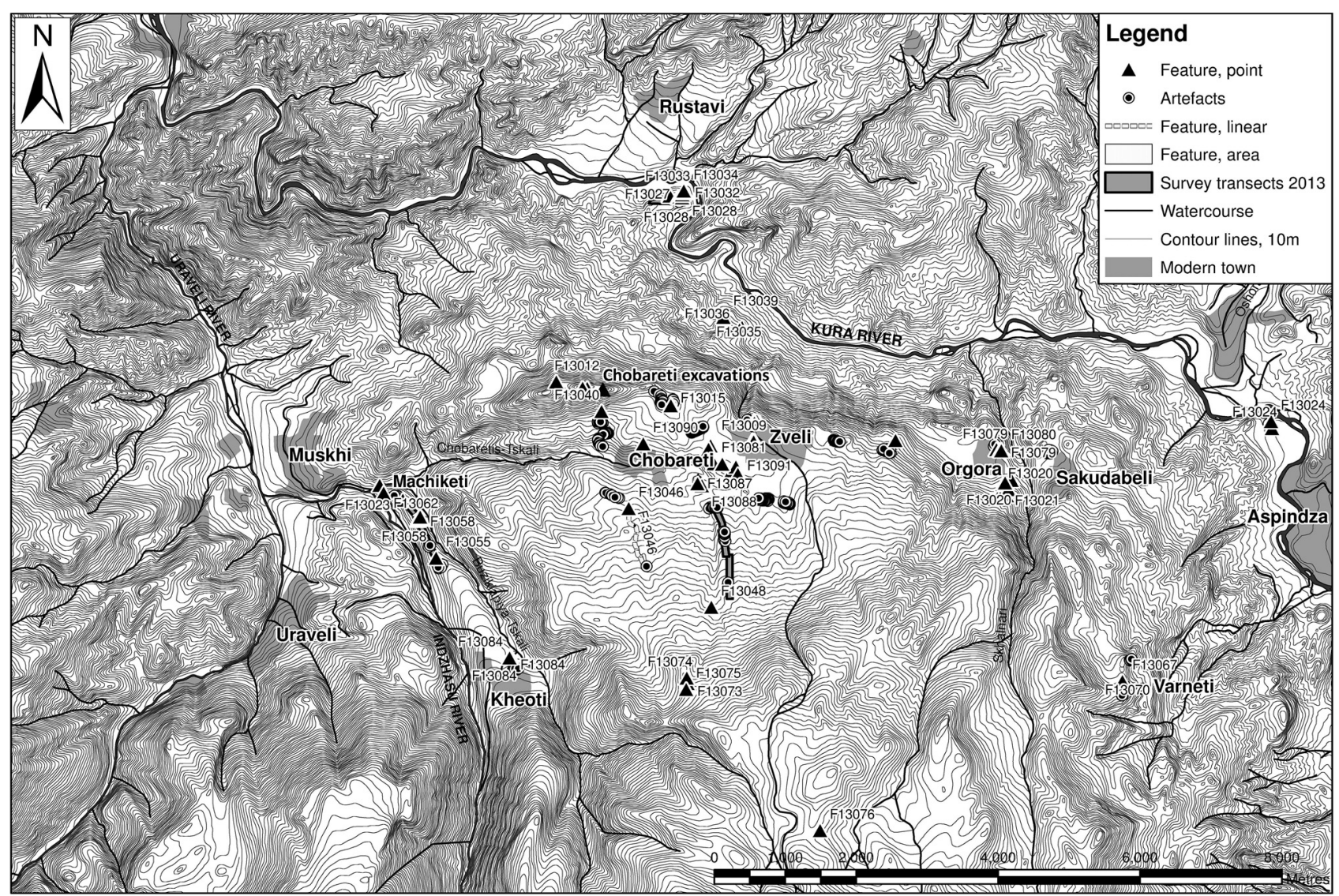

Fig. 2 : Map of the LAG survey region showing features recorded in 2013.

preferences for settlement location. While the focal area was the elevated plain between Muskhi and Sakudabeli, at roughly $1500 \mathrm{~m}$ above sea level (asl), the survey also made preliminary investigations of the two most contrasting elevations within the study area - the highland yayla and the alluvial floor of the Kura River valley.

The Kura River is a regionally important waterway that flows through eastern Anatolia and southern Caucasia (Fig. 1). Within the study area the river banks vary from steep, narrow ravines to wide, lowlying floodplains. Intensive survey of a freshly ploughed but unplanted field (F13024) on the flats immediately above the river's south bank, at $1075 \mathrm{~m}$, yielded few artefacts, though one of these is a Hellenistic dish base of fine, buff fabric, probably imported, providing some slight evidence of a Hellenistic presence on this low-lying plain opposite Aspindza.

Further downstream, a level area on a bow crescent meander in the river was also investigated. This rectilinear portion of level ground (rising only $3.5 \mathrm{~m}$ over a distance of $550 \mathrm{~m}$ ) within an otherwise hilly area is overlooked by a conical hill to the west and a ruined tower across the river to the east, near Rustavi village. The tower on the eastern bank is recorded on Soviet maps with the typical notation for ruins, but there are no features identified on the western bank. Here, there is an elevated alluvial plain above the river course where the steep banks make flooding of the area improbable.

A transect of $550 \mathrm{~m}$ length was walked across this level area. Though very few surface artefacts were found, a series of perpendicular wall lines were recorded (F13027, F13028, F13031, F13032 and F13033). These form rectilinear and curvilinear cells immediately above the river course with more extensive linear stone features extending across the level area behind, apparently a settlement with associated corrals (Fig. 3). One of the larger, linear features comprises two parallel stone alignments that form a double wall. The walls are built from locally available cobbles and boulders, using dry stone techniques. The few artefacts found near to the settlement, including coarse pottery and a fragment of metal, provide little information about the site's chronology, which is suspected to be medieval.

Above the elevated plain, where Chobareti is situated, mixed deciduous forest of oak, hornbeam and beech grows between elevations of roughly 1600 - 

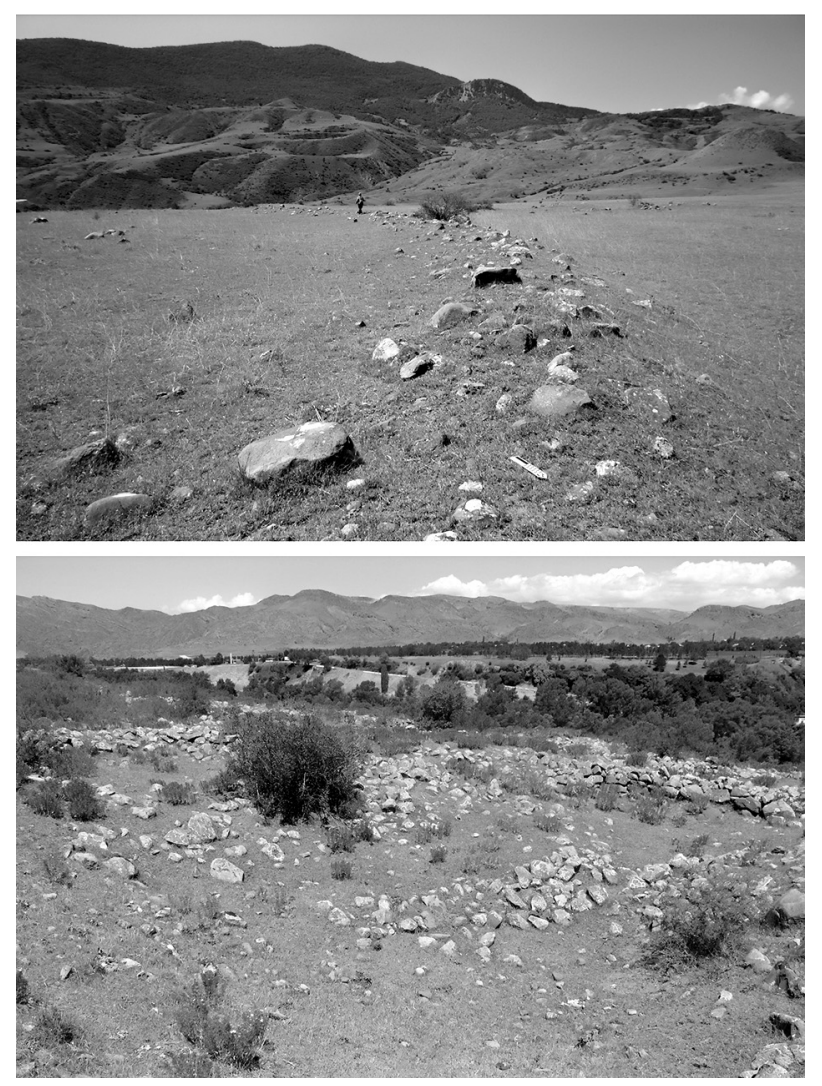

Fig. 3 : Walls and structures on the south bank of the Kura River near Rustavi (F13027-F13033).

$1900 \mathrm{~m}$. Recent palynological studies indicate that the composition of this forest would have varied in the past, with the tree line extending to between $2000-2800 \mathrm{~m}$ at the beginning of the $3^{\text {rd }}$ millennium B.C. (Shatilova et al. 2011: 147). During the $2^{\text {nd }}$ millennium, birch and pine which grew at the upper border of the forest zone gave way to oak and hornbeam (Kvavadze and Narimanishvili 2010; Connor et al. 2004). Coniferous forests still exist in the Samtskhe-Javakheti highlands, notably in plantations within the study area. The upper and lower boundaries of the forest zone are today anthropogenic.

In the forest belt, a cluster of four features was investigated on the northern slope of the mountains at $1800 \mathrm{~m}$. Each consists of roughly circular stone alignments located on a gentle gradient beside a natural clearing in the forest. The two smaller features (F13072 and F13075) are slightly mounded (50 cm and $40 \mathrm{~cm}$ height) and are oval shaped in plan, having a longer east-west measurement. Basalt rocks of varying sizes encircle these two mounds, both of which are identifiable as cromlech burials or low kurgans.
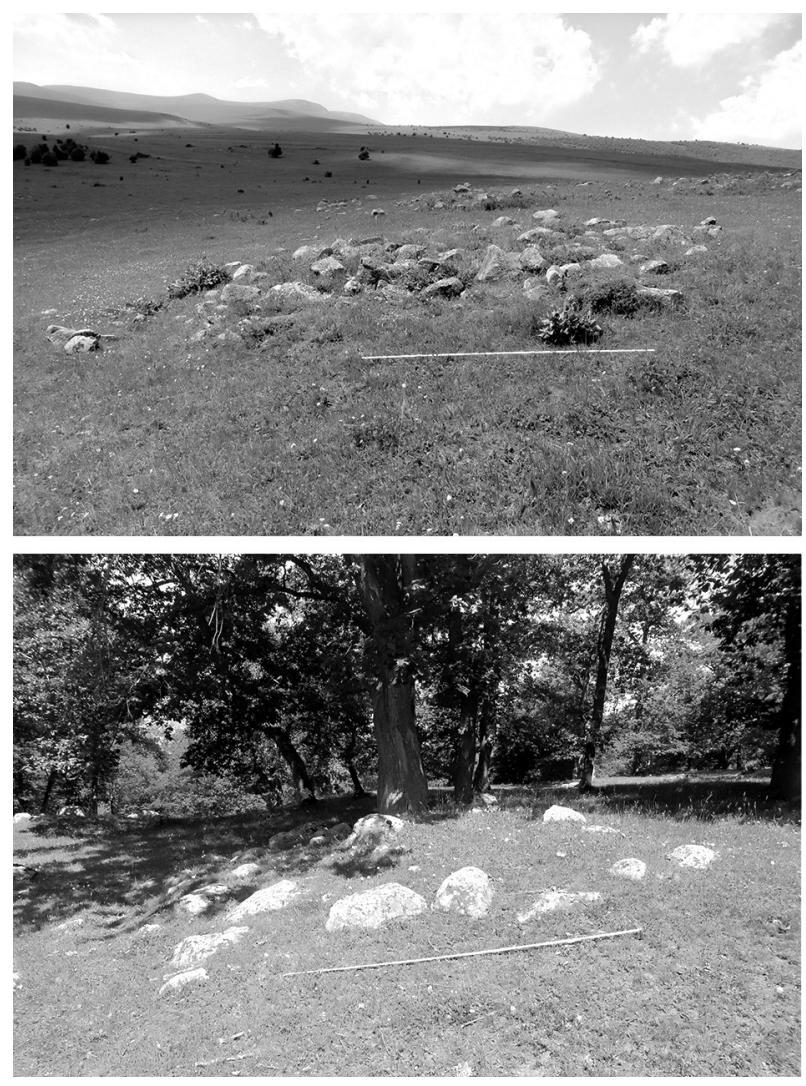

Fig. 4 : Built stone features on the upper slopes and yayla south of Zveli; cromlech (F13076, above) and stone circle (F13073, below).

Of the two larger structures, one incorporates a $3 \mathrm{~m}$ wide 'entrance' of parallel stones extending $5 \mathrm{~m}$ to the south of the circular feature (F13073). The stone circle is constructed to incorporate naturally occurring boulders and includes a large boulder in the centre (Fig. 4); a modern pit has been excavated within the feature. This is a substantial structure at $19 \mathrm{~m}$ by $15.4 \mathrm{~m}$ with piled stone walls up to $1.7 \mathrm{~m}$ wide. It is possible that this stone circle is a burial, given its proximity to the smaller encircled mounds, but it may also have been used as a pen, or have had different uses at different times. The second large stone circle (F13074), partly disturbed by tree growth, is similarly constructed of basalt boulders of varying sizes which form a boundary $2-2.5 \mathrm{~m}$ wide.

Grassy plains extend across the highlands to the south where extensive features were noted. A cluster of cromlech burials, consisting of low mounds covered by basalt cobbles, were located on a gentle slope at an altitude of $2000 \mathrm{~m}$ (Fig. 4). The cromlechs vary in size and detail but each comprises a rough circle of stones and low mound, occasionally with a slight depression in the centre (such as 


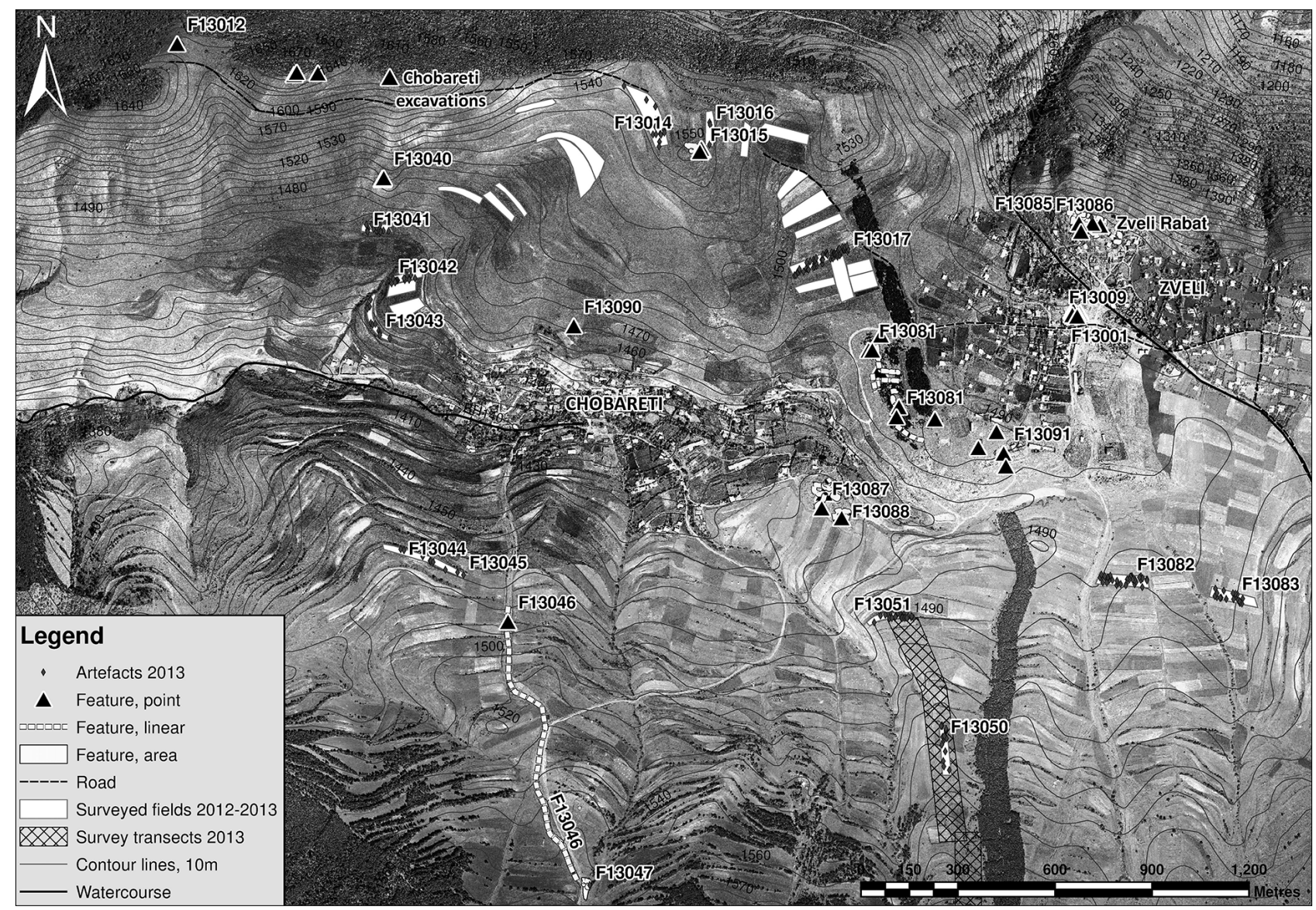

Fig. 5 : Map of Chobareti and Zveli localities showing features recorded in 2013.

F13076). To the north and east of these burials are terracing and rectilinear wall lines. Features visible on satellite imagery and aerial photographs suggest a substantial field system and walled enclosures. At present it is not possible to suggest a date for the formation of the field systems or the enclosures: they remain to be investigated, along with the extent and variety of the burial clusters on the high plains.

The presence of kurgans and stone circles, cromlechs and wall lines indicate multiple periods of landscape use and modification at high altitudes. The identification of clustered burials within the forest and on the high plains is significant, since similar structures are also found on the plain at $1500 \mathrm{~m}$, to the east and west of Zveli village (F13081). Likewise, terracing and walls on the yayla indicates the altitudinal extent of landscape modification in this region.

The findings outlined above provide clear evidence for pre-modern land use spanning a range of some $1000 \mathrm{~m}$ elevation, from the extensive linear stone features at $2000 \mathrm{~m}$ on the high plateau to those located beside the Kura River at 1040 m. The distri- bution of large stone circles, kurgan burials and cromlechs extending from the upper border of the forest zone and onto the high plateau, highlight the significance of this seasonally accessible landscape zone.

\section{Chobareti and Zveli}

The upland valley that runs parallel to the south of the Kura River, where Chobareti and Zveli villages are located, was a major focus for survey in 2013, especially intensive survey (Fig. 5). Zveli is at a slightly higher elevation than Chobareti, on raised ground that runs up to the escarpment of the Kura River valley. To the south of Chobareti and Zveli is a patchwork of tiered, terraced fields (Fig. 6). Chobareti lies at the base of the valley, in an enclosed position that is flanked by the gradually rising upper slopes to the south, and to the north by a tall ridge formed by three peaks. Excavations currently in progress on the easterly of the peaks have located Early Bronze Age structures and burials, and a medieval occupation (Kakhiani et al. 2013). 


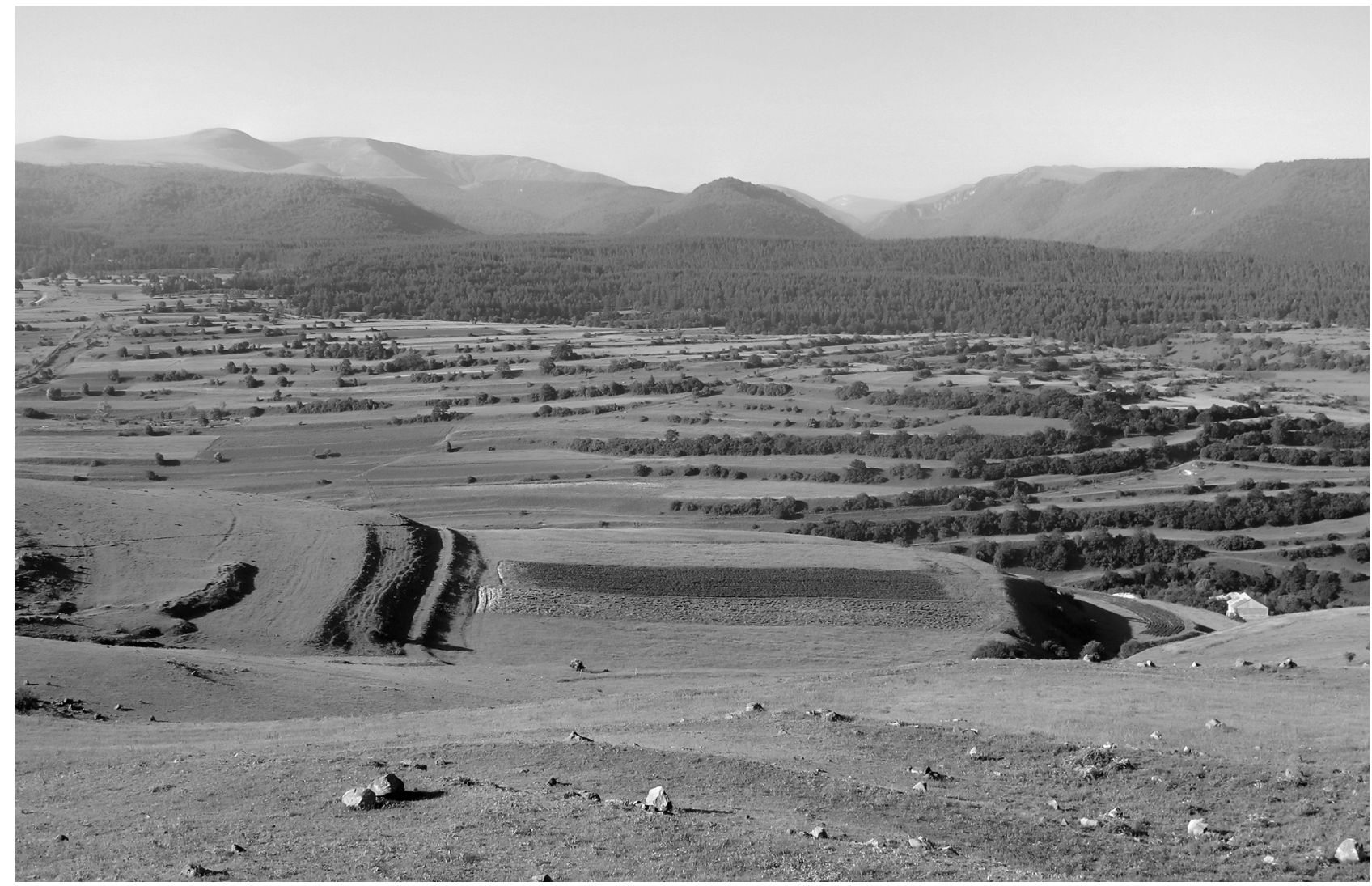

Fig. 6 : The valley at Chobareti; view facing south across terraced fields. Intensive survey unit SU008 (F13042) is the ploughed field in the foreground.
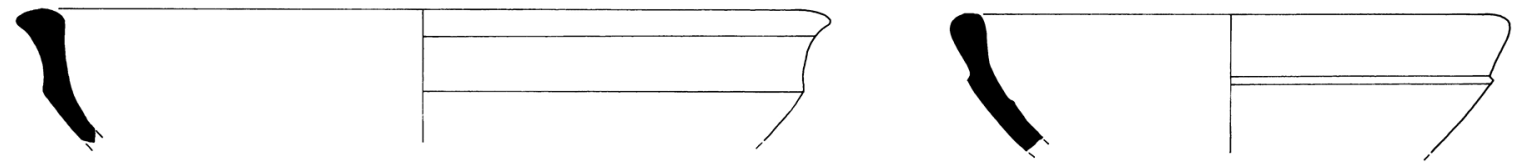

F13041-01

F13042-01

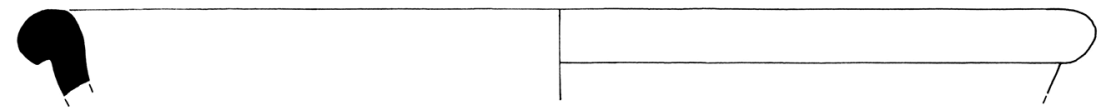

$\mathrm{F} 13042-02$

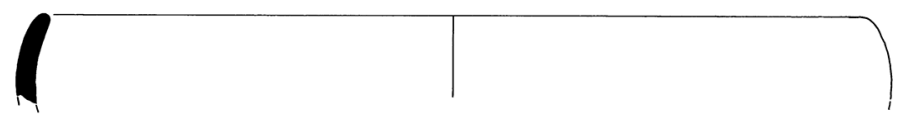

F13017-01

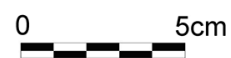

Fig. 7 : Late Iron Age and Hellenistic ceramics from intensive survey north of Chobareti. 
On the grassy, upper slopes north of Chobareti are a number of $20^{\text {th }}$-century military trenches from when this area was a Soviet frontline. Intensive survey of the terraced fields across the lower valley slopes both north and south of Chobareti produced some of the highest artefact counts of the 2013 season and include a wide chronological range. Among collections from two nearby fields north of Chobareti (F13041, F13042) are two Achaemenid style, carinated bowls and other Late Iron Age to Hellenistic sherds (Fig. 7 and Appendix 3). The position of these fields, on the south-facing lower slopes, is close to a large flat area that provides good visibility along the valley in both directions. The typochronology of surface artefacts also shows consistency in fields south of Zveli: finds from three intensive survey units (F13051, F13082 and F13083) include several Roman-period items, spanning the $1^{\text {st }}$ to $7^{\text {th }}$ centuries A.D. The presence of discrete Iron Age, Hellenistic and Roman material in the intensive fields is coupled with a relative lack of prehistoric artefacts, though flaked obsidian was present in F13017, near Zveli, as well as a fragment of black and grey hand-made gritty ware with deeply incised, cross hatched lines.

In the area just west of Zveli, crossed by the gas pipeline, a cluster of Bronze Age kurgans have been previously recorded and some excavated (F13081AC, H). During the 2013 survey, the excavated kurgans were documented as well as a series of other features in the vicinity, not previously reported (Fig. 5). These include a linear, North-South aligned stone embankment (F13081D), $5 \mathrm{~m}$ wide and running for $80 \mathrm{~m}$, that turns to the east, gradually veering to the northeast where there is an area with cobbled walls running east-west (F13081E).

Further South, where there is a fir tree plantation, runs an East-West aligned series of parallel wall features $(\mathrm{F} 13081 \mathrm{~F}-\mathrm{G})$. In a small clearing are remains of a possible kurgan $(\mathrm{F} 13081 \mathrm{H})$ and a large, curvilinear embankment to the west (F13081I). Though the latter feature follows the natural topography, it appears to have undergone substantial modification to exaggerate the existing contour. Aside from the kurgans, other features documented in this area may represent a further embankment associated with the F13081 structures, or possibly relict terraces and field boundaries. There has been modern quarrying to the southeast of the forested area, along a south facing cliff, and beyond are ruined concrete structures belonging to Soviet agricultural/industrial installations of the mid- to late- $20^{\text {th }}$ century (F13091).
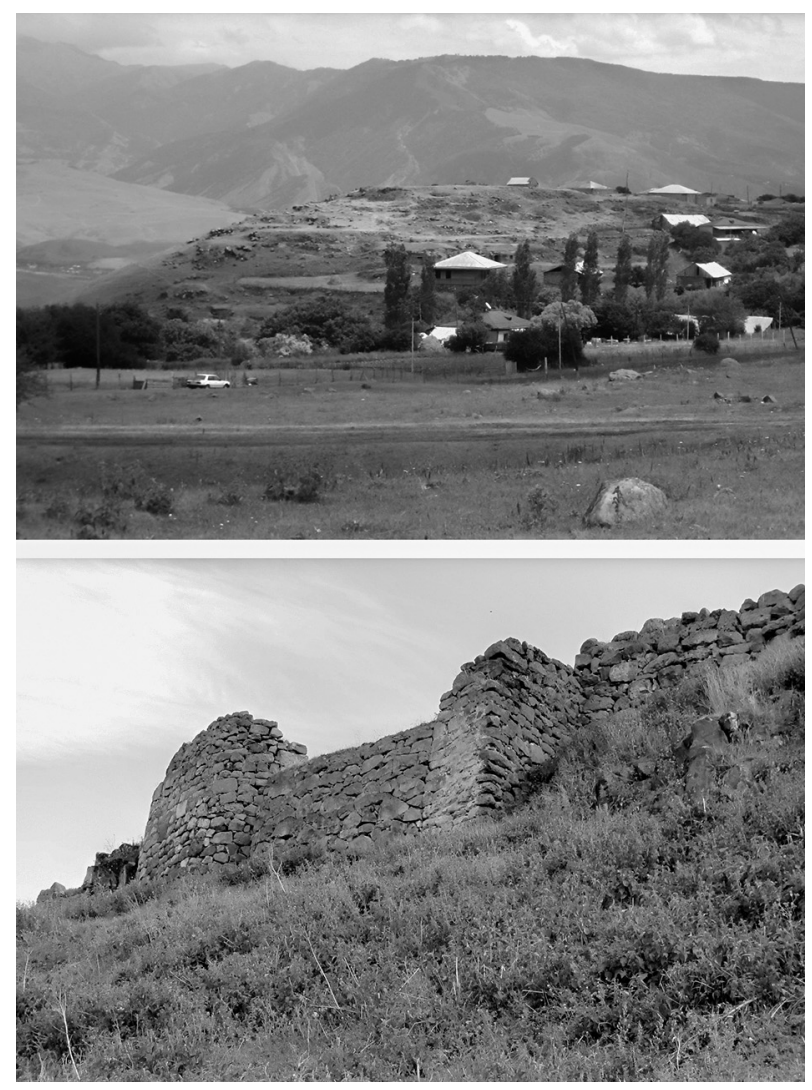

Fig. 8 : Zveli Rabat (F13086), view of the mound from the south (above) and fortification wall along the escarpment edge to the north (below).

\section{Zveli Rabat}

On the northwest edge of Zveli, along the top of the escarpment overlooking the Kura valley, is an important, multi-period site atop a raised mound known locally as the Rabati or Rabat (F13086) (Fig. 8). The name derives from the Arabic term rabad or ar-Ribaat, which denotes a district or quarter of a town or city that is outside the inner city or citadel (Lévi Provençal 2013). Along the northern edge there stand sections of a fortification wall overlooking the steep valley slopes. The site, which covers almost $3000 \mathrm{~m}^{2}$, was clearly a settlement and may have had multiple functions during its long occupation. Today, the mound is comprised of several terraced levels, well-preserved drystone walls, rectilinear structures, earthworks and artefact scatters. The raised ground affords extensive views in all directions, especially down into the Kura River valley, and is intervisible with the three peaked ridge north of Chobareti. 


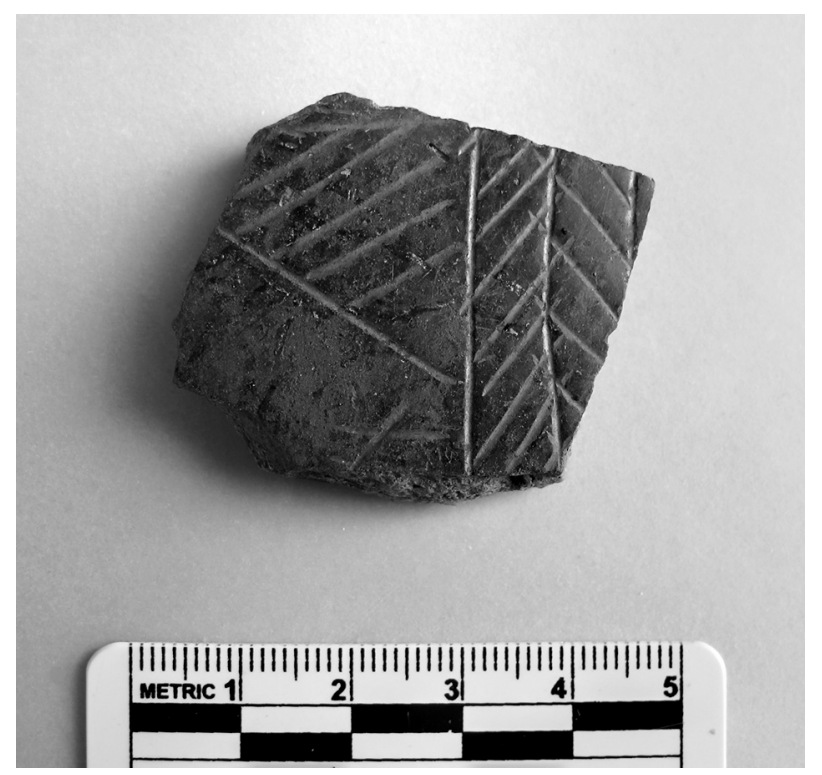

Fig. 9 : Burnished and incised sherd from Zveli Rabat (F13085C).

The Zveli Rabat was archaeologically investigated during the 1950s and 1970s, when Bronze Age and medieval remains were identified (Djaparidze 1992: 195-197). As part of the LAG survey, preliminary investigations consisted of assessing the area and commencing a detailed record of visible features. Numerous wall lines represented by buried and partially buried features, as well as some standing structures were documented across the north and west of the site. These appear to be medieval to modern in date, comprised of basalt, dry stone constructions (e.g. F13086H-J). Particularly well preserved, on the north side of the site (running East-West), is a portion of the outer fortification wall (F13086V), with the remains of casements, one rectilinear and one semicircular (Fig. 8). Some sections of the wall are preserved to a height of around $4 \mathrm{~m}$ and rest on a lower terrace. Another noteworthy find is a small modern shrine $(\mathrm{F} 13086 \mathrm{M})$ constructed from loose stones framed by spolium with a carved cross.

To the east and south, some old structures are still in use as houses, barns and storage areas. On the south side in particular, there are numerous pits close to modern dwellings. On the top level, facing South, is a series of large depressions (F13086B) which are probably old excavation trenches, perhaps from Gambashidze's work in the 1970s. Beyond the confines of the Rabat proper, an artefact scatter was recorded on disturbed ground to the Southwest (F13085A-C), below the level of the visible structures. Ceramics, bone, and lithics are eroding from the ground in three nearby locations. The ceramics include hand-made red-black burnished ware, medieval sherds, and one black incised and burnished Early Kurgan/Bedeni phase sherd (F13085C) (Fig. 9). The presence of medieval and post-medieval building remains and artefact scatters featuring Early to Middle Bronze Age pottery suggest superimposition of several cultural layers and longlived occupation of this place.

\section{Verana}

The medieval settlement of Verana (F13087) is situated on the southeast outskirts of Chobareti village, on a natural rise beside a stream running eastwest. Site recording in 2013 considered the extent of the mounded settlement, documented the partly standing church and also some of the prominent wall lines. Further work is required to document buildings and determine the extent of the site, particularly to the south, as it merges into modern fields; also to find out whether the mound was artificially built up as a result of multiple occupation levels, or has a single main occupation phase.

The settlement consists of a flat topped mound which drops sharply to the northeast. Visible structures are primarily on the west and north side, arranged in a grid pattern around higher ground and following the contours of the rise. The remains of structures consist of dry stone, rectilinear buildings that are densely clustered, especially to the west. Down the middle of the mound, running NorthSouth, then veering in a curve to the east, is a wall made of large boulders, which appears to have acted as a partition between the east and west portions of the settlement. On the south end of this wall is a menhir-like standing stone.

In the east part of the site are the standing remains of a church (F13088), on ground that is somewhat lower than the western portion and appears devoid of other structures; the settlement may continue further east, behind the church. The church itself is a substantial building surrounded by an enclosure wall (Fig. 10). It has a central nave with barrel-vaulted aisles to the north and south sides and a narthex to the West. The entrance was via a doorway in the centre of the western wall which opened into the narthex. The north aisle has a semi-circular domed apse at the eastern end that is partially preserved, as does the nave apse; the south aisle probably had an identical apse, but nothing of it remains. The building is constructed of dressed stone blocks with a rubble and lime mortar core. Sections of the aisle barrel vaults are well preserved within the north and south aisles that are constructed of thin basalt 


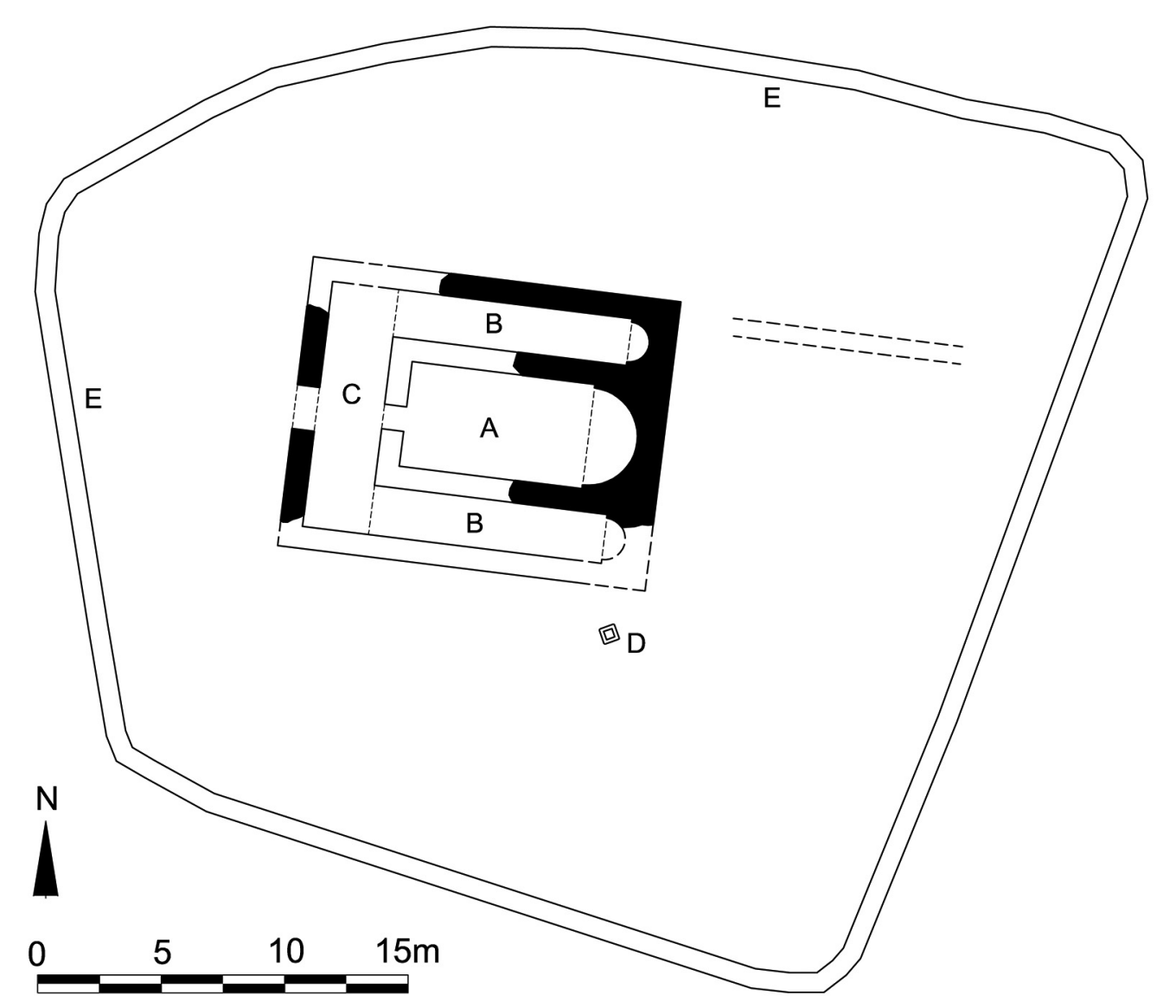

Fig. 10 : Plan of Verana Church (F13088).

A - nave; B - aisles; C - narthex; D - standing cross base; E - stone enclosure wall.

voussoirs set radially in mortar. Outside, at the southeast corner of the church, is a square stone base carved with a Bolnisi cross in a circle on one face and a shallow square slot on top, presumably for holding a standing cross.

The size of the church suggests that it was a focal point for communities in the immediate surroundings, and indicates the prominent position of medieval Verana. From the mound, the views to the west, down the valley, are particularly commanding, reinforcing the east-west topography as a communication route. The settlement's status in relation to other places and landmarks, including the location of Chobareti, the hillside road to the south of the village (F13046, discussed below), the ridge to the North, and other sites of medieval occupation including Zveli Rabat, remain to be examined.

\section{Kheoti and Machiketi}

In the Southwest of the study area, site recording, intensive field-walking, and a $1.25 \mathrm{~km}$ transect were conducted over a ridge flanked by deeply cut streams aligned at a right angle to Chobareti Ikala, the stream that runs westwards from Chobareti (Fig. 2). At the top of the valley is Kheoti village, located at $1420 \mathrm{~m}$ elevation on the northern slope of the Erusheti ridge, in the Kheotistsqlis gorge. To the West, across a deep gully through which runs Indzhasu River, is Orstepi, where ruins are marked on the Vilayet and Soviet maps, and a stone tower is perched on a high point overlooking the gorge. From Kheoti, the steadily sloping ridge runs in a northwest direction, ending at the ruined settlement of Machiketi, east of Muskhi.

To the North of Kheoti village stands a church with adjoined bell tower and partitioned rooms that represent a single building complex (F13084) (Fig. 11). The church has a single nave with semicircular apse at the southeastern end and roofed and barrel vaulted side chapel to the North. On the western side of the nave is a narthex, and on the South is an open court (perhaps once a covered aisle) leading to the belfry which is adjoined to the southern side of the nave. The nave and narthex are constructed of dressed stone blocks set in mortar, and are unroofed 


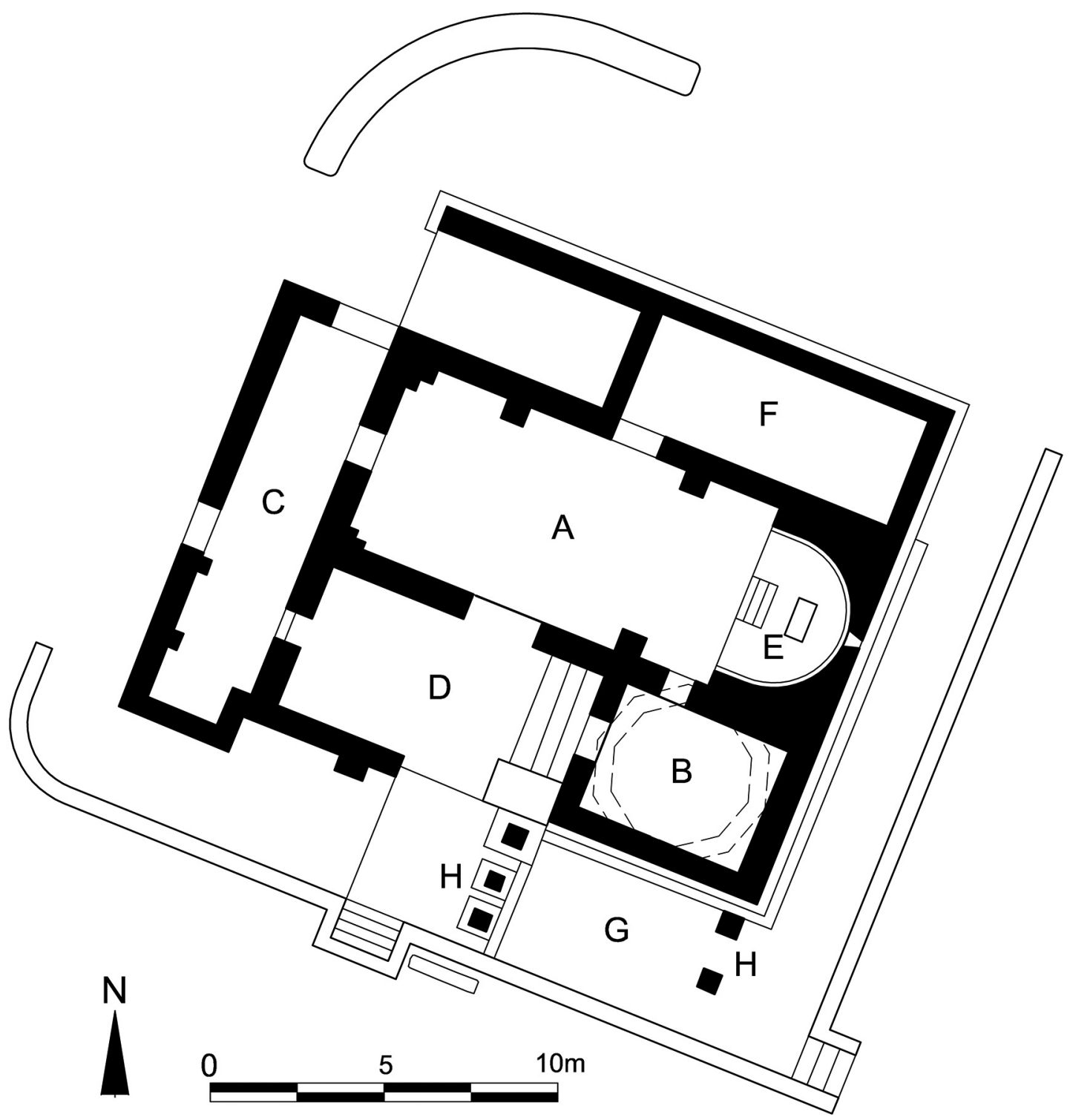

Fig. 11 : Plan of Kheoti Church (F13084). A - nave; B - bell tower; C - narthex; D - court/hall; E - altar; F - side chapel; $\mathbf{G}$ - gravestones; $H$ - standing crosses.

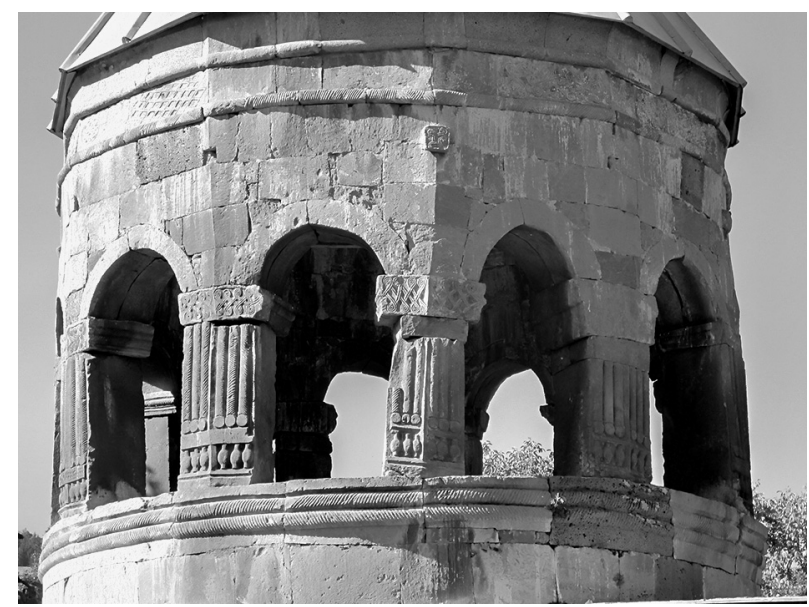

Fig. 12 : Kheoti Church, detail of the belfry upper storey showing arches and carved columns and capitals.

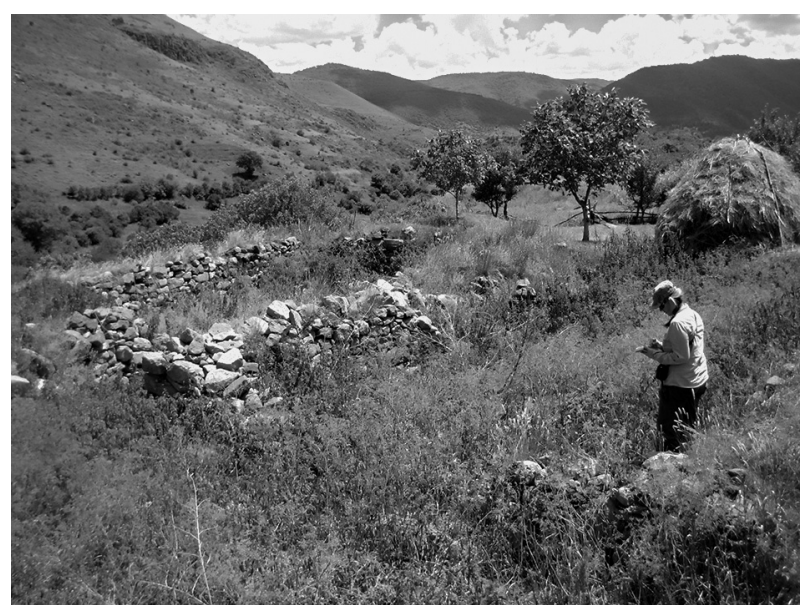

Fig. 13 : Recording settlement remains along the ridge north of Kheoti (F13058). 
and preserved to around 2-3 $\mathrm{m}$ in height. The base of the belfry and the east exterior wall of the nave are built of finely dressed stone blocks with no apparent mortar. There are three standing crosses and the stone bases for others on the southwestern side together with carved gravestones. The whole complex has been heavily restored and rebuilt in 1996, as indicated by a modern inscription and the carved reliefs and sculptures built into its walls. The church and belfry are surrounded by numerous structures including substantial wall remains and a spring, creating a single, unified monastery complex. There are also some medieval Georgian inscriptions written in Asomtavruli script, dating to the $14^{\text {th }}-15^{\text {th }}$ centuries, built into the complex walls.

Kheoti's bell tower is reconstructed but its components are well preserved and the structure retains distinctive features of medieval ecclesiastical architecture (Fig. 12). Since the $13^{\text {th }}$ century, the construction of belfries was common in Georgia. Usually the belfry and the church stand separately. Although the interconnected church and belfry arrangement at Kheoti is rare, there are parallels with the belfry of Saphara monastery (Beridze 1970: 41-2). At the Kheoti church there are two storeys. The first is an enclosed room forming a chapel, under which was a tomb (Muskhelishvili et al. 1954: 15). The belfry's walls are well built using two kinds of fine, grey and red coloured sandstone. The upper storey is open and has eleven arches supported by pillars (the uneven number of arches is also a rare feature). The columns that support the arches, cornices on both floors and the first-floor windows are decorated in the same manner with ornamental carvings that consist mostly of geometric, latticework shapes and other motifs including crosses and running spirals; the base of the pillars are carved with what appears to be a row of vessels. On the basis of the ornamentation, the choice of subject and stone carving techniques, Kheoti's construction is dateable to between the $14^{\text {th }}$ and $15^{\text {th }}$ centuries (Beridze 1970: 42), although it may have earlier elements, suggested by different styles of relief sculpture that are incorporated into its walls.

Along the ridge northwest of Kheoti, several ruined structures, including three discrete settlements, all within $1 \mathrm{~km}$ of each other, were detected using the systematic transect method. On the central stretch of the ridge is a cluster of rectilinear and curvilinear dry stone buildings that are preserved below ground level (F13058) (Fig. 13). One structure recorded in detail has a sub-circular plan and is divided into two compartments; in the western compartment is an entranceway to the north and a fire- place and chimney built into the west side. To the east of the settlement is a pit where the ground has collapsed to expose a tunnel that is said to lead between the settlement and the base of the gorge to the east (F13057).

Further down-slope to the north is a smaller settlement (F13060), circular in plan with a ruined stone chapel in the centre (F13059), and bounded by a circuit wall, of which a well preserved section stands to the north. At the foot of the ridge, where the gorge meets the stream originating at Chobareti, is a substantial ruined settlement identified as Machiketi (F13062), which is marked on the Vilayet map. There are numerous stone terrace walls and structural remains on a mounded area, and across the stream to the north is a ruined church which is currently being restored and rebuilt (F13023).

\section{Orgora and Sakudabeli}

East of the enclosed uplands at Chobareti, terraces along the steep side of the Kura River valley make up a series of north-facing platforms between the upper and middle slopes. Orgora and Sakudabeli villages occupy two such adjacent terraces, at elevations of $c a .1375 \mathrm{~m}$, separated by a deep ravine that cuts into the hillside. The villages lie barely $1 \mathrm{~km}$ apart, and are both sited at the base of the upper slope, set back from spurs forming promontories along the valley side (Fig. 14).

Sakudabeli, the easterly of the two villages, is situated at the very back of the terrace; a spring flows from the side of a rounded hillock which is the location of the modern cemetery. In front of the village there is an oval area of flat farmland, which the road skirts around in a wide loop. Intensive survey in one of these fields (F13065) found a high artefact count and a noteworthy presence of Roman-period material. Among the collections are the rim of a fine ware dish with red slip, thought to be an import of the $5^{\text {th }}$ or $6^{\text {th }}$ century A.D., closed cooking pots, the neck of a transport amphora and thin-walled vessel glass.

Behind Orgora, the slopes rise less sharply than at Sakudabeli. Southwest of the village, multiple terraces enclose thin strips of cultivated land while the southeast side is undulating pasture where there is a suspected medieval settlement. The gas pipeline, continuing from Chobareti in the west, runs along the foot of the upper slope. Buried and partially exposed walls of buildings are eroding from the bank on the north side of the terrace (F13021). On grassland to the South is a light scatter of artefacts (F13018), among them the ring-footed base of a fine bowl, ledge rims of dishes, a fragment of storage jar 


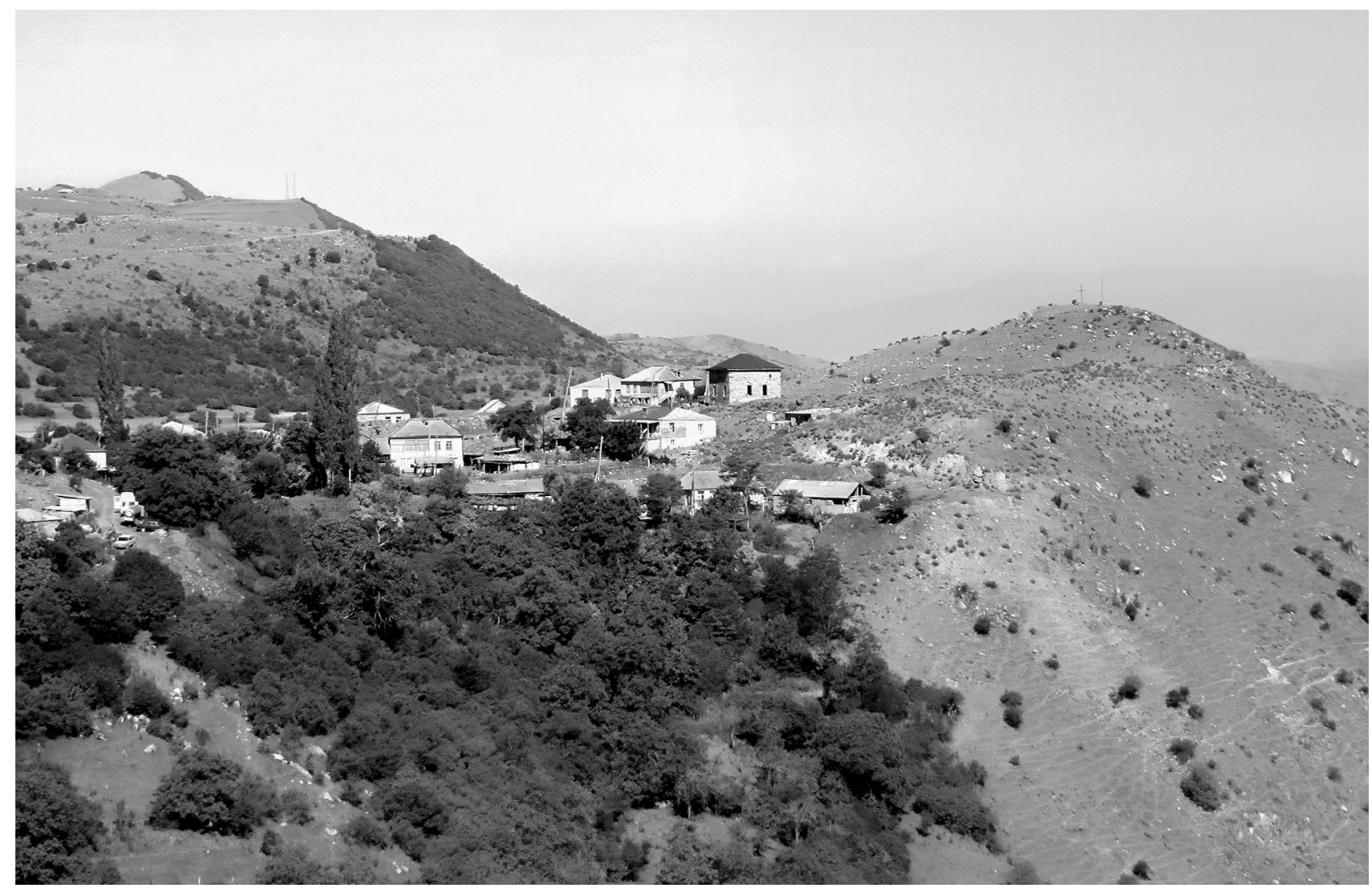

Fig. 14 : Orgora, view facing west across the mound north of the village (F13078), at the right of the picture. The peaks above Chobareti are visible in the distance, at the far left of the picture.

with incised wavilinear decoration and a storage vessel handle of earlier date than the other, medieval and post-medieval sherds. Another small ceramic scatter beside the pipeline (F13019) features red-coated and hand-made coarsewares.

The ground rises steeply above the pasture, and running directly uphill and perpendicular to the slope, is a road formed by parallel embankments of large boulders at each side (F13020) (Fig. 15). On the higher slopes, above $1380 \mathrm{~m}$, this roadway changes course and snakes across the hillside to the west, perhaps towards the deserted village of Kuri. A similar hollow way, formed by parallel stone embankments that border a depression paved with stone cobbles, climbs the slope south of Chobareti (F13046) (Fig. 15). These roadways, whose chronology is uncertain and which may have been built up over long spans of time, appear to form routes connecting villages and linking settlements with highland pastures, but they may also have had significance as boundary markers.

On the north side of Orgora village the ground rises towards the edge of the terrace where there is a mosque (F13022), derelict and now used as a barn.
It is built of mortared basalt blocks with dressed stone at the corners, at the windows and framing the main arched doorway (Fig. 16). The interior, which is well preserved but deteriorating, has the remains of a timber-framed second storey at the northern end with carved timber columns supporting a decorative timber panelled ceiling with ornate frieze and cornice and a central dome constructed of lathe and plaster. The plastered walls are painted with floral motifs, as is the carved stone mihrab set into the southern wall. The dome is more lavishly painted, with flowers, fabric swags and Arabic inscriptions. Another square plan mosque, in the same vernacular architecture, was documented in the settlement of Ghobieti (F13035). Both are suspected to date from the $18^{\text {th }}$ or $19^{\text {th }}$ century.

To the north of the mosque there are many ruined and partially buried structures across raised ground of the promontory overlooking the Kura River valley (F13078) (Fig. 14). The condition of the ruins and the landscape position are comparable to Zveli Rabat (F13086), and the mound appears to be a similarly long-lived site. Ceramics on the surface include Late Iron Age and Roman sherds. Southeast of the rise, a 

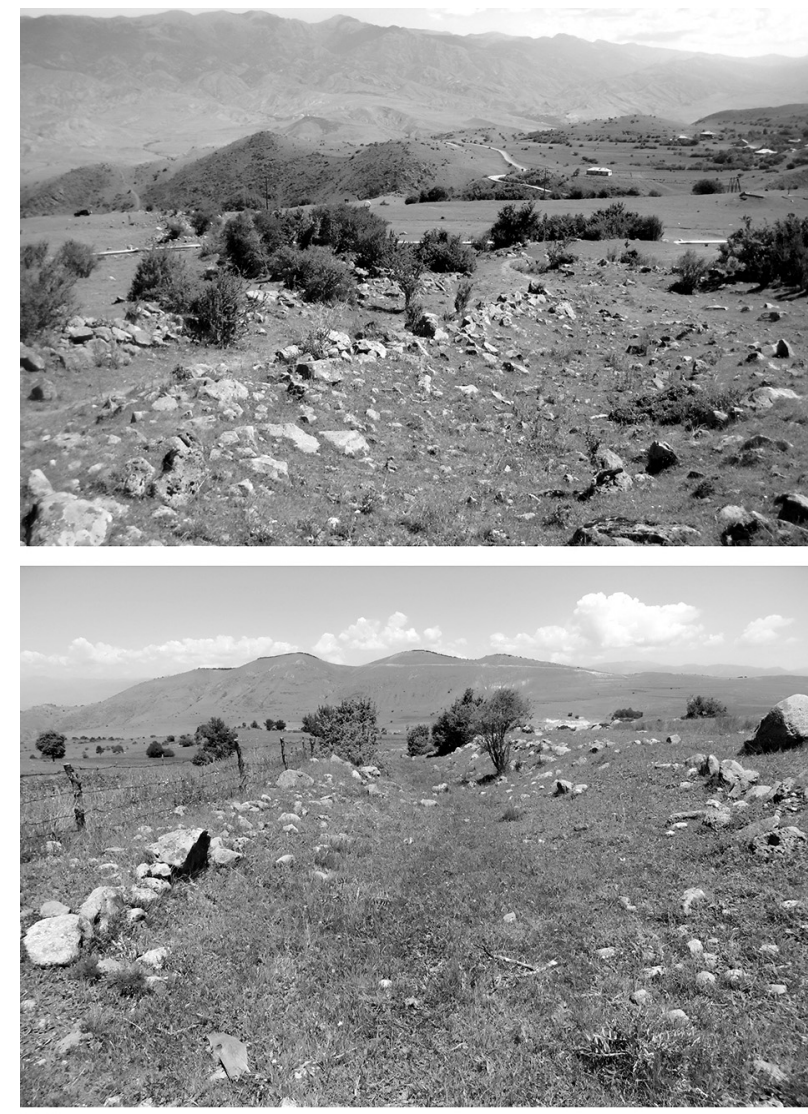

Fig. 15 : Hillside roadways, at Orgora (F13020, above) and Chobareti (F13046, below).

mechanical cutting has been made in recent years. Several features are exposed in the profile, and artefacts and human bone are eroding from the cutting (F13079). Noteworthy features include a stone lined cist grave with skeleton visible in section which has been bisected (F13079A) and a pithos burial is immediately beside (F13079C), around $3 \mathrm{~m}$ below the top of the bank and $1 \mathrm{~m}$ below a stone structure. Ceramics along the cutting include probable Early Iron Age black gritty wares, an Early Bronze Age vessel in burnished fabric and Hellenistic sherds. The documented features and artefacts show this place to have multiple phases and functions spanning several millennia.

\section{Varneti}

The Varneti complex of sites, named after a ruined medieval settlement in the vicinity which is marked on the Vilayet and Soviet maps, is located along the upper middle slopes of the Kura Valley, $2.5 \mathrm{~km}$ South of Sakudabeli. The site's location was disclosed by a local informant in Sakudabeli and first visited during a brief inspection with Dr. Kakhiani
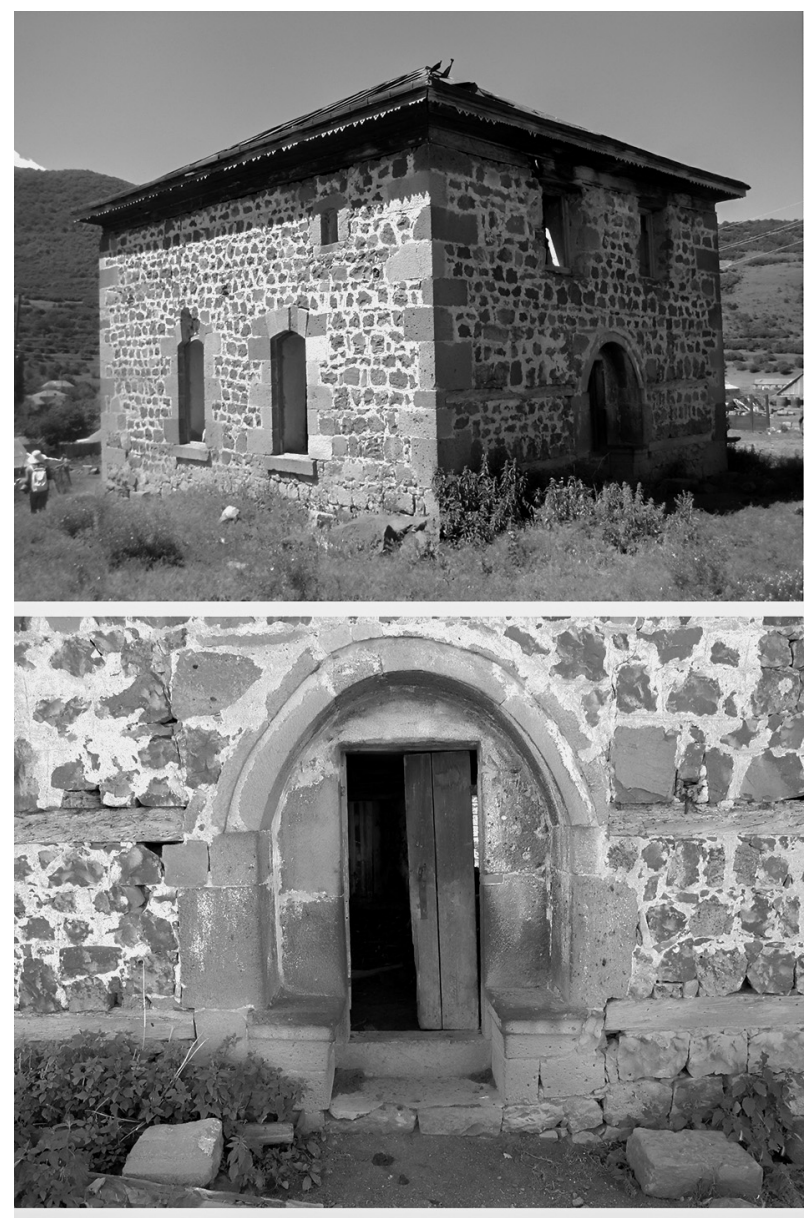

Fig. 16 : Mosque on the north side of Orgora village (F13022).

before more detailed recording took place. There are several different features located between 1565$1670 \mathrm{~m}$ asl that relate to multiple periods and types of occupation. The features include an exposed cultural deposit, settlement mound, a complex of terrace walls and structures, artefact scatters, and a hill-fort (Fig. 17).

A recent landslip has exposed a $c a .3 \mathrm{~m}$ high profile that contains cultural material in the upper $2 \mathrm{~m}$ (Varneti 1, F13066); a measured section drawing of the profile documented four distinctive strata, where the cultural layer rests on a flattened surface of dark greyish brown sediment, perhaps artificially levelled, overlying a base of rocky colluvium (Fig. 18). Ceramics from this deposit date principally from the Early Bronze Age and include distinctive red and black Kura-Araxes style pottery (Fig. 19 and Appendix 3). Directly above the cutting is a flat terrace that is likely to be a settlement location. Nearby, to the east of F13066, is a $c a .15 \mathrm{~m}$ high mound with cultural material on the surface of the eroded sides and 


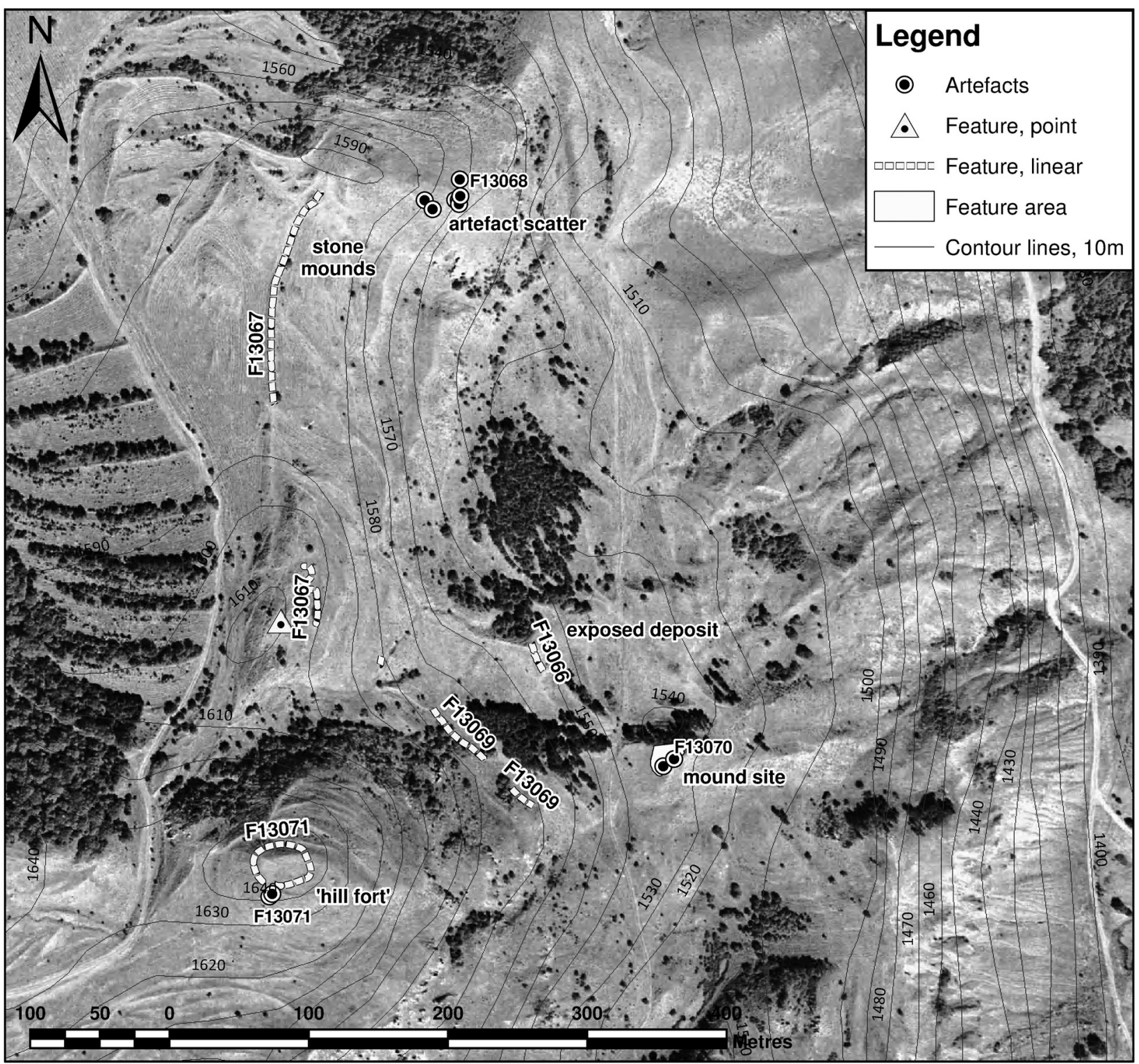

Fig. 17 : Map of Varneti showing features recorded in 2013.

apparently eroding from depths of up to $5 \mathrm{~m}$ below the summit (Varneti 2, F13070). The artefact scatter here is composed of hand-made ceramics, obsidian tools and large animal bones; one noteworthy find is a heavily worked flint bifacial tool which may be identified as a sickle (Fig. 20, F13070-21) ${ }^{6}$. Preliminary analysis of the ceramics and lithics suggests that Varneti 2 is earlier than Varneti 1, perhaps spanning the Chalcolithic to Early Bronze Age.
Above the cutting and mound is Varneti 3 (F13067), a steep, summit area of stone terrace walls and dry stone structures that may be the remains of small buildings or enclosures. A wide, linear embankment (F13067) extends to the north, leading to an isolated conical hill where an artefact scatter (F13068) includes possible Late Bronze Age ceramics and a single flaked quartzite tool but no visible structures (Fig. 19 and Appendix 3). Between fea-

6) Examples of this type of tool have been found in other parts of Georgia and are dated to the Chalcolithic and Early Bronze Age (Nebieridze 2001: 25). Flint sickle blades, including one of a similar form and material to the Varneti find, have been excavated at Tiselis Seri (Gogochuri and Orjonikidze 2007: 46, pl. xxxiv, no. 133-3). 

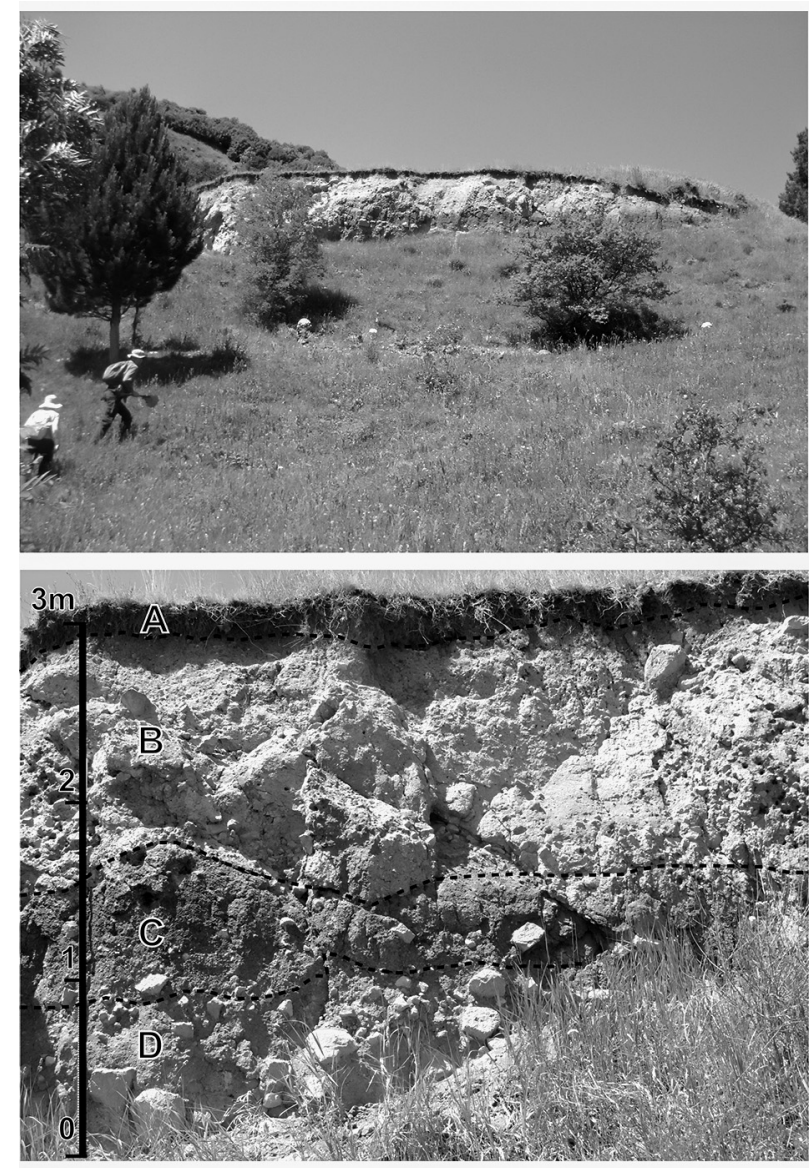

tures F13067 and F13068 there are nine stone mounds that may be kurgans. Uphill to the west of F13066 there are several areas of terrace retaining walls constructed of field stone (F13069) that may relate to more recent farming activity. High above these features, at $1670 \mathrm{~m}$ elevation, is a rounded enclosure constructed of unmortared local field stone, 2-3 m wide that encircles the top of the hill (Varneti 4, F13071). A section of the wall extends downhill slightly on the western side, forming a ramped entranceway. Artefacts on the eroded southern slope, below the stone enclosure wall, include flaked obsidian and pottery dating from the Early Bronze Age to the Iron Age.

The Varneti complex of sites appears to be a significant area of long-term occupation. Overall, most of the features appear to date from the Early Bronze Age, whilst the hill fort (F13071) may also have Iron Age occupation and the mound (F13070) has earlier Chalcolithic material. The exposed profile with pottery, lithics and bone eroding out (F13066) is likely

Fig. 18 : Varneti 1 (F13066), an exposed stretch of embankment containing Early Bronze Age deposits: A - topsoil; B - rocky, pale coloured silt containing pottery, lithics and bone; C - dark brown clayey soil; D - colluvium.

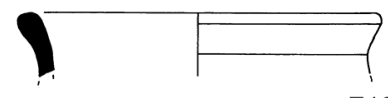

F13066-04
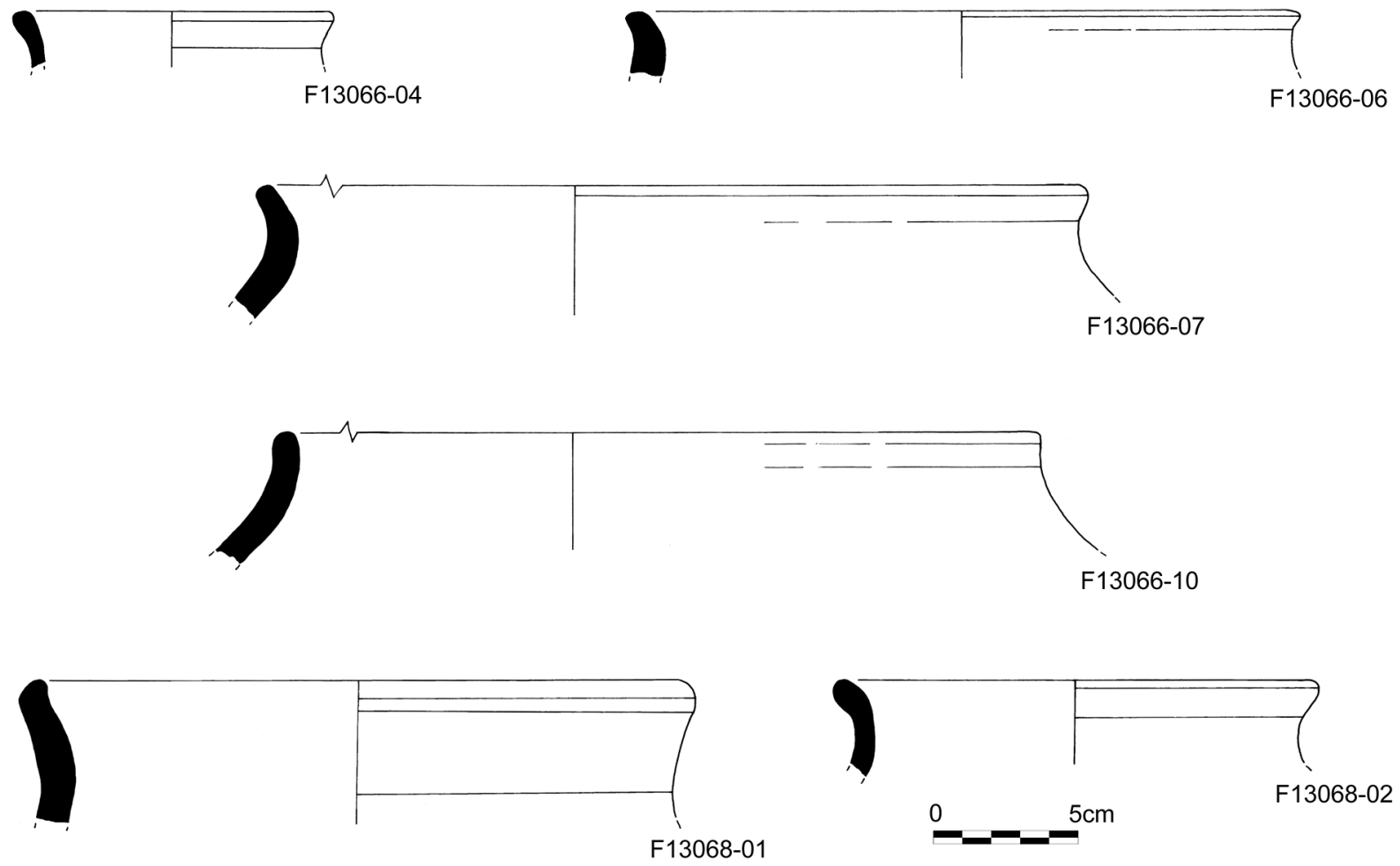

Fig. 19 : Ceramics from Varneti, selected examples from the exposed profile (F13066) and the hilltop artefact scatter (F13068). 

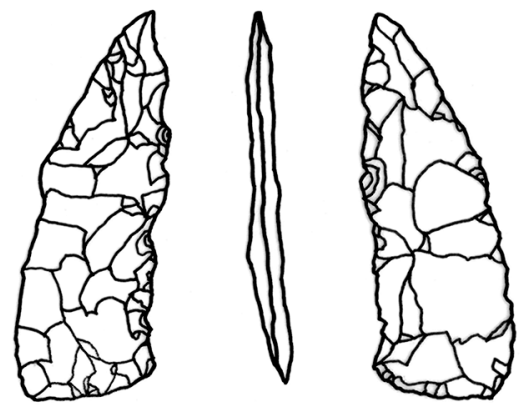

F13070-21
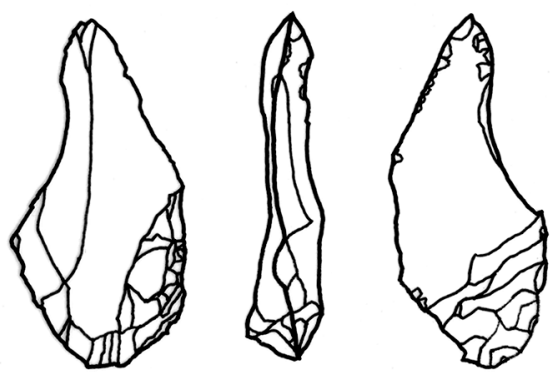

F13070-22
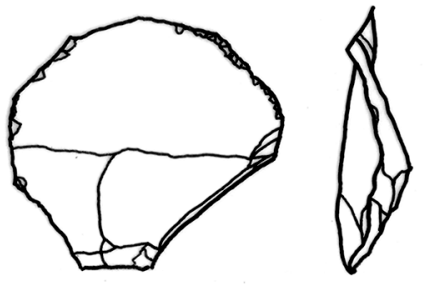

F13070-24

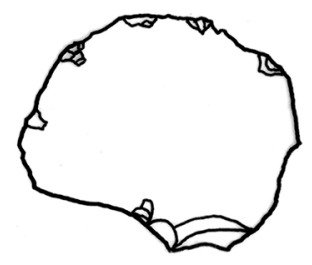

F13070-23
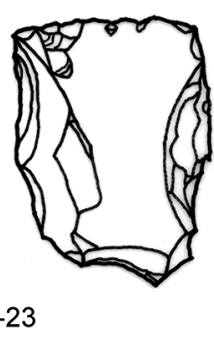

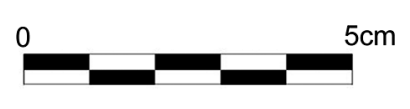

Fig. 20: Lithics from Varneti 2 (F13070), collected on the south side of the mound.

to be a settlement area, and so too the mound F13070; the enclosure at F13071 has strong parallels with hill-forts documented in Armenia, such as Tsilkar (Top Kar), Ashot-Yerkat and Poloz-Sar fortresses (Smith et al. 2009: 281ff., pl. 68b, 68c, $68 \mathrm{~d}$ ). The date of terracing and structures at F13067 are unknown but may be the remains of pastoral activities; the terrace walls of F13068 are probably much more recent. This multi-period occupation area requires further investigation and documentation, including of the medieval village of Varneti which lies $500 \mathrm{~m}$ to the east.

\section{CONCLUSION}

The highland environment between Akhaltsikhe and Aspindza presents a varied and complex array of archaeological features in different locations, elevations and topographies. From the alluvial floodplain and gorge of the Kura River to the middle slope terraces and high yayla grasslands, there are abundant remains of human occupation that span multiple time periods and include evidence of settlement, land modification, agriculture, burial and movement. Our preliminary investigations raise a number of themes and research questions that will be pursued during future field work, including identification of temporal trends in settlement location and regional interconnections through time.

The use of extensive and systematic methods resulted in multi-scalar data and qualitative differences in the type and date of recorded material. This is demonstrated by the range of artefacts from intensive survey units as opposed to unsystematic collections from extensive sites. Preliminary dating of diagnostic artefacts from intensive survey shows the Roman and medieval periods to be most strongly represented ( $57 \%$ of analysed sherds), and relatively few pre-Roman artefacts. Conversely, artefacts from extensive sites include material dating mostly from the Bronze Age, as well as a few but distinctive Iron Age and Hellenistic items. Intermediate factors in the presence and patterning of surface artefacts in cultivated fields, such as redeposition through manuring, might explain the possible correspondence between high artefact counts and proximity to villages. Nevertheless, spatial patterns in the type and date of artefacts hint that ploughsoil assemblages are representative of past occupation areas. 
Moreover, archaeological excavations in this part of the Caucasus suggest that material from successive time periods tends to be horizontally distributed rather than accumulating in vertically stratified settlement sites (tells, or höyüks) which are such a prominent feature of Anatolia and Mesopotamia. This implies that in locations which were occupied over multiple time periods, such as Zveli Rabat, Orgora and Varneti, people established themselves beside rather than on top of the preceding occupation in the immediate vicinity. The relationships between the features at these composite sites raise interesting questions on settlement patterns and land use strategies as well as the placement of burials. At a larger geographical scale there are also consistencies in the distribution of these long-lived sites, each of which are positioned along the top of the escarpment, overlooking the Kura River.

This report provides a summary framework of ongoing landscape archaeology research in the Samtskhe-Javakheti region, in which we have out- lined the initial results in key survey areas and sites recorded during the 2013 season. This provides an indication both of the success of a survey methodology which integrates intensive survey with systematic and extensive site recording, and of the diversity of archaeological features present in this highland environment. Future research will add to this record and pursue further thematic questions, allowing us to investigate the interconnections between sites of similar age and to examine patterns of land use across different time periods and topographic zones. Evidence of cultural interactions at local and regional scales, conducted over long time periods, demonstrate this region's significance within the South Caucasus highlands and at the larger scale of Anatolia and the Near East. The results of this ongoing research provide a first step towards framing the study area as a complex archaeological landscape.

$$
\text { W.A. et al. }
$$

\section{BIBLIOGRAPHY}

Baramidze, M. and Pkhakadze, G., 2007: Comprehensive Technical Report on Archaeological Investigations at Site IV-261, Chorati Village, Akhaltsikhe District, KP 241, Tbilisi: Otar Lordkipanidze Centre of Archaeology of the Georgian National Museum.

Beridze, V., 1970: Samtskhis khurotmodzgvruli dzeglebi (Architectural Sites of Samtskhe), Tbilisi.

Burney, C. and Lang, D. M., 1971: The People of the Hills: Ancient Ararat and Caucasus, London: Weidenfeld and Nicolson.

Chubinishvili, T., Tatishvili, T. and Gambashidze, O., 1957: "Arkheologicheskie razvedki v yujnikh raionakh gruzii (Meskheti-Javakheti) v 1953-1955 (Archaeological surveys in the southern regions of Georgia (MeskhetJavakheti) in 1953-1955)", Sovetskaya Arkheologia 4: 116-127.

Chubinishvili, T., 1963: Amiranis Gora, Tbilisi: Sabchota Saqartvelo.

Connor, S., Thomas, I., Kvavadze, E.V., Arabuli, G. J., Avakov, G. S. and Sagona, A., 2004: "A survey of modern pollen and vegetation along an altitudinal transect in southern Georgia, Caucasus region", Review of Palaeobotany and Palynology 129: 229-250.

Djaparidze, O., 1992: Sakartvelos Arkeologia II. Eneolit-Adre Brinjaos Khana (Georgian Archaeology II. From the Eneolithic to the Early Bronze Age), Tbilisi: Metsniereba.
Djaparidze, O., Kikvidze, I., Avalishvili, G. and Tsereteli, A., 1981: Meskhet-Javakhetis archeologiuri eqspediciis Mushaobis Shedegebi (Results of the Archaeological Expedition of Meskhet-Javakheti), Tbilisi: Metsniereba.

Dzhikiya, S.S., 1958: Prostrannyi reestr vilaieta Giurdzhistan, Tom 3: Issledovaniye (The Territorial Register of the Vilayet of Gurjistan), Tblisi: Gruzinskaya SSR Akademiya Nauk.

Gambashidze, I. and Mindiashvili, G., 2006: Archaeological Excavations at the Klde Settlement and Cemetery, Report, Tbilisi: Otar Lordkipanidze Centre of Archaeology of the Georgian National Museum.

Gambashidze, O. and Kvijinadze, K., 1979: "Raboti Meskhet-Javakhetskoi ekspeditsii (Works of the MeskhetJavakheti expedition)", Polevye Arkheologicheskie Issledovaniia v. 1976 g: 55-60.

Gambashidze O., Kvijinadze, K. and Orjonikidze, A., 1980: "Raboti Meskhet-Javakhetskoi ekspeditsii (Works of the Meskhet-Javakheti expedition)", Polevye Arkheologicheskie Issledovaniia v. $1977 \mathrm{g:}$ 78-84.

Gambashidze, O. and Kvijinadze, K., 1981: "Raboti Meskhet-Javakhetskoi ekspeditsii (Works of the MeskhetJavakheti expedition)", Polevye Arkheologicheskie Issledovaniia v. $1978 \mathrm{~g}$ : 57-64.

- 1982: "Meskhet-Javakhetinskaya ekspeditsiia (Meskhet-Javakheti expedition)", Polevye Arkheologicheskie Issledovaniia v. $1980 \mathrm{~g}: 29-31$. 
Gambashidze, O., Kvijinadze, K., Tkeshelashvili, O. and Licheli, V., 1984: "Meskhet-Javakhetinskaya ekspeditsia (Meskhet-Javakheti expedition)", Polevye Arkheologicheskie Issledovaniia v. $1981 \mathrm{~g}$ : 18-21.

Gambashidze, O., Kvijinadze, K., and Abramishvili, M., 1985: "Otchot o rabote Meskhet-Javakhetinskoi ekspeditsii (Report of the Meskhet-Javakheti expedition)", Polevye Arkheologicheskie Issledovaniia v. 1982 g: 3137.

Gambashidze, O., Gambashidze, Ir., Kvirkvaia, R. and Kvijinadze, K., 2004: "Meskhet-Javakhetis archeologiuri eqspedicia (Meskhet-Javakheti archaeological expedition 1989-1991)", in Mokle Savele Angarishebi 1989-1992, Tbilisi: Centre for Archaeological Studies.

Gamkrelidze, G. (ed.), 2010: Rescue Archaeology in Georgia: The Baku-Tbilisi-Ceyhan and South Caucasian Pipelines, Tbilisi: Georgian National Museum.

Gogochuri, G. and Orjonikidze, A., 2007: Comprehensive Technical Report on Archaeological Investigations at Site IV-293 Tiselis Seri KP 203. Tbilisi: Otar Lordkipanidze Centre of Archaeology of the Georgian National Museum.

Kakhiani, K., Sagona, A., Sagona, C., Kvavadze, E., Bedianashvili, G., Massager, E., Martin, L., Herrscher, E., Martkoplishvili, I., Birkett-Rees, J. and Longford, C., 2013: "Archaeological investigations at Chobareti in southern Georgia, the Caucasus", Ancient Near Eastern Studies 50: 1-138.

Kiguradze, T. and Sagona, A., 2003: "On the origins of the Kura-Araxes cultural complex", in Smith, A.T. and Rubinson, K. (eds.), Archaeology in the Borderlands: Investigations in Caucasia and Beyond, Los Angeles: Cotsen Institute of Archaeology, University of California: 38-94.

Kvavadze, E. and Narimanishvili, G., 2010: "The palaeolandscapes of the Tsalka Plateau in the Late Pleistocene and Holocene", in Gamkrelidze, G. (ed.), Rescue Archaeology in Georgia: The Baku-Tbilisi-Ceyhan and South Caucasian Pipelines, Tbilisi: 587-606.

Lévi Provençal, E., 2013: "Raba", in Bearman, P., Bianquis, Th., Bosworth, C.E., van Donzel, E. and Heinrichs, W.P. (eds.), Encyclopaedia of Islam, Second Edition. Brill Online. Accessed 08 November 2013. http://referenceworks.brillonline.com.ezp.lib.unimelb.edu .au/entries/encyclopaedia-of-islam-2/rabad-SIM 6151

Licheli, V., Rcheulishvili, G., Kasradze, M., Rusishvili, R., Kalandadze, N., Papuashvili, N., Kazakhishvili, L. and Gobejishvili, G., 2007: Archaeological Investigation at Site IV-266/320, KP211/212, Atskuri Vil- lage, Akhaltsikhe Region, Tbilisi: Otar Lordkipanidze Centre of Archaeology of the Georgian National Museum.

Marro, C. (ed.), 2012: After the Ubaid: Interpreting Change from the Caucasus to Mesopotamia at the Dawn of Urban Civilization (4500-3500 B.C.), Paris: De Boccard.

Muskhelishvili, L., Khidasheli, Sh. and Japaridze, V., 1954: Gudarekhis pirveli da meore arqeologiuri kampaniis angarishi 1938 da 1939 tsts. (Reports of the First and Second Gudarekhi Archaeological Campaigns 1938 and 1939), Tbilisi.

Nebieridze, L., 2001: “Adresamitsatmokmedo kulturis namosakhlari okribashi (Site of early husbandry culture in Okriba)", Dziebani. Journal of the Centre for Archaeological Studies, Georgian Academy of Sciences 8: 23-33.

Palumbi, G., 2008: The Red and Black. Social and Cultural Interaction between the Upper Euphrates and the Southern Caucasus Communities in the Fourth and Third Millennium B.C., Rome: Studi di Preistoria Orientale.

Rayfield, D., 2012: Edge of Empires: A History of Georgia, London: Reaktion Books.

Shatilova, I., Mchedlishvili, N., Rukhadze, L. and Kvavadze, E., 2011: The History of the Flora and Vegetation of Georgia (South Caucasus), Tbilisi: Georgian National Museum.

Smith. A.T. and Rubinson, K.S. (eds.), 2003: Archaeology in the Borderlands: Investigations in Caucasia and Beyond, Los Angeles: Cotsen Institute of Archaeology, University of California.

Smith, A.T., Badalyan, R.S. and Avetisyan, P., 2009: The Archaeology and Geography of Ancient Transcaucasian Societies. Volume 1. The Foundations of Research and Regional Survey in the Tsaghkahovit Plain, Armenia, Chicago: The Oriental Institute of the University of Chicago.

Svanidze, M., 1987: “Animal husbandry and beekeeping in the Pashalik of Akhaltsikhe (Childir) according to the "Detailed register of the Vilayet of Gurjistan" 1595 AD", in Kara, G. (ed.), Between the Danube and the Caucasus. A Collection of Papers Concerning Oriental Sources on the History of the Peoples of Central and South-Eastern Europe, Budapest: Akadémiai Kiadó: 331337.

Tekinalp, M. and Ekim, Y., 2005: Sazpegler: A Medieval Settlement in North Eastern Anatolia, Ankara: Gazi University Research Center for Archaeology. 
APPENDIX 1 :

Catalogue of features and sites mentioned in the text. Chronology estimates are coded according to the periodisation presented in Appendix 2.

\begin{tabular}{|c|c|c|c|}
\hline Feature code & Locality & Description & Chronology \\
\hline $\begin{array}{l}\text { F13017 } \\
\text { (SU003) }\end{array}$ & Zveli & $\begin{array}{l}\text { Artefact scatter, intensive survey field on slopes } \\
\text { west of Zveli }\end{array}$ & $\begin{array}{l}\text { EBA, HEL, ROM, } \\
\text { LANT, EMED-LMED, } \\
\text { OTT }\end{array}$ \\
\hline $\begin{array}{l}\text { F13018 } \\
\text { (SU004) }\end{array}$ & Orgora & Settlement, artefact scatter & LANT, MED, OTT \\
\hline F13019 & Orgora & Settlement, artefact scatter & MED-LMED \\
\hline F13020 & Orgora & $\begin{array}{l}\text { Road formed by parallel embankments with } \\
\text { large boulders, on hillside south of Orgora }\end{array}$ & MED, OTT \\
\hline F13021 & Orgora & $\begin{array}{l}\text { Settlement, buried and partially exposed struc- } \\
\text { tures }\end{array}$ & MED-LMED \\
\hline F13022 & Orgora & Mosque, standing structure & OTT, 19C \\
\hline F13023 & Machikheti & $\begin{array}{l}\text { Church, ruined, beside road and stream near } \\
\text { Machikheti, currently undergoing restoration }\end{array}$ & MED \\
\hline $\begin{array}{l}\text { F13024 } \\
\text { (SU005) }\end{array}$ & Aspindza & $\begin{array}{l}\text { Artefact scatter, intensive survey field on flats } \\
\text { above south bank of Kura River }\end{array}$ & HEL, SOV \\
\hline F13027-F13033 & Rustavi & $\begin{array}{l}\text { Settlement, ruined; dry stone structures, with } \\
\text { long wall alignments to south, possible corrals, } \\
\text { above south bank of Kura River }\end{array}$ & MED \\
\hline F13035 & Ghobieti & Mosque, standing structure & OTT, 19C \\
\hline $\begin{array}{l}\text { F13041 } \\
\text { (SU007) }\end{array}$ & Chobareti & $\begin{array}{l}\text { Artefact scatter, intensive survey field on slopes } \\
\text { north of Chobareti }\end{array}$ & $\begin{array}{l}\text { LIA, HEL, ROM, } \\
\text { LANT, MED-LMED, } \\
\text { OTT }\end{array}$ \\
\hline $\begin{array}{l}\text { F13042 } \\
\text { (SU008) }\end{array}$ & Chobareti & $\begin{array}{l}\text { Artefact scatter, intensive survey field on slopes } \\
\text { north of Chobareti }\end{array}$ & $\begin{array}{l}\text { LIA, HEL, ROM, } \\
\text { LANT }\end{array}$ \\
\hline F13046 & Chobareti & $\begin{array}{l}\text { Road formed by parallel embankments with } \\
\text { large boulders, on hillside south of Chobareti }\end{array}$ & MED-OTT \\
\hline F13051 (SU014) & Chobareti & $\begin{array}{l}\text { Artefact scatter, intensive survey field on terrac- } \\
\text { es south of Chobareti }\end{array}$ & $\begin{array}{l}\text { ROM, LANT, EMED- } \\
\text { LMED, OTT }\end{array}$ \\
\hline F13058 & Kheoti & Settlement, structures & MED-OTT \\
\hline F13059-F060 & Kheoti & Settlement, structures & MED-OTT \\
\hline F13062 & Machikheti & Settlement, structures & MED-OTT \\
\hline F13065 (SU023) & Sakudabeli & Artefact scatter & $\begin{array}{l}\text { HEL, ROM, LANT, } \\
\text { MED, LMED, OTT }\end{array}$ \\
\hline F13066 & Varneti & $\begin{array}{l}\text { Exposed cutting along embankment caused by } \\
\text { landslip, containing cultural deposits }\end{array}$ & EBA \\
\hline F13067 & Varneti & Terraces and structures & MED-OTT \\
\hline F13068 & Varneti & Artefact scatter on steep conical hill & EBA-LBA \\
\hline F13069 & Varneti & Terraces & MED-19C \\
\hline F13070 & Varneti & $\begin{array}{l}\text { Mound with cultural material and deposits erod- } \\
\text { ing from its sides }\end{array}$ & CHA, EBA \\
\hline F13071 & Varneti & $\begin{array}{l}\text { Stone wall encircling summit of a rounded hill } \\
\text { (hill fort); artefact scatter }\end{array}$ & EBA, LBA, EIA \\
\hline F13072 & Tuzlug & Mound, kurgan & LBA \\
\hline F13073 & Tuzlug & $\begin{array}{l}\text { Structure or monument made of large boulders } \\
\text { in circular formation }\end{array}$ & EIA \\
\hline F13075 & Tuzlug & Mound, kurgan & LBA \\
\hline F13076 & Tuzlug & Mound, kurgan & LBA \\
\hline
\end{tabular}




\begin{tabular}{|l|l|l|l|}
\hline Feature code & Locality & Description & Chronology \\
\hline F13078 & Orgora & Artefact scatter, buried structures & HEL, ROM, MED \\
\hline F13079 & Orgora & $\begin{array}{l}\text { Structures and burials exposed in cutting of } \\
\text { terrace; artefact scatter }\end{array}$ & $\begin{array}{l}\text { EBA, LBA, EIA, LIA, } \\
\text { HEL, ROM, MED, } \\
\text { OTT }\end{array}$ \\
\hline F13081 & Zveli & $\begin{array}{l}\text { Barrows, kurgans, stone features; buried, above } \\
\text { ground and excavated structures }\end{array}$ & LBA, MED-LMED \\
\hline F13082 (SU027) & Zveli & $\begin{array}{l}\text { Artefact scatter, intensive survey field on terrac- } \\
\text { es south of Zveli }\end{array}$ & $\begin{array}{l}\text { LIA, HEL, ROM, } \\
\text { MED, LMED OTT }\end{array}$ \\
\hline F13083 (SU028) & Zveli & $\begin{array}{l}\text { Artefact scatter, intensive survey field on terrac- } \\
\text { es south of Zveli }\end{array}$ & $\begin{array}{l}\text { LANT, MED-LMED, } \\
\text { 19C }\end{array}$ \\
\hline F13084 & Kheoti & Church, monastery; standing structures & MED \\
\hline F13085 & Zveli & $\begin{array}{l}\text { Zveli Rabat, southwest side: buried features, } \\
\text { artefact scatter }\end{array}$ & EBA, MBA, LBA \\
\hline F13086 & Zveli & $\begin{array}{l}\text { Zveli Rabat: settlement, buried and standing } \\
\text { structures, artefact scatters }\end{array}$ & EBA, MED, OTT \\
\hline F13087 & Chobareti & $\begin{array}{l}\text { Verana: settlement, buried and standing struc- } \\
\text { tures }\end{array}$ & EMED-LMED \\
\hline F13088 & Chobareti & Verana Church & MED-LMED \\
\hline F13091 & Zveli & $\begin{array}{l}\text { Structures; concrete industrial and agricultural } \\
\text { buildings south of Zveli }\end{array}$ & SOV \\
\hline
\end{tabular}

APPENDIX 2 :

Chronology used by the LAG Project in 2013.

\begin{tabular}{|l|l|l|}
\hline Period name & Abbreviation & Date range \\
\hline Lower Palaeolithic & LPAL & $2,000,000-100,000$ B.P. \\
\hline Middle/Upper Palaeolithic & PAL & $100,000-14,000$ B.P. \\
\hline Mesolithic & MES & $12,000-7000$ B.C. \\
\hline Neolithic/Chalcolithic & NEO & 7000-4800 B.C. \\
\hline Chalcolithic & CHA & 4800-3500 B.C. \\
\hline Early Bronze Age & EBA & 3500-2500 B.C. \\
\hline Middle Bronze Age & MBA & 2500-1500 B.C. \\
\hline Late Bronze Age-Early Iron Age & LBA & 1500-1100 B.C. \\
\hline Early Iron Age & EIA & 1100-700 B.C. \\
\hline Late Iron Age/Classical & LIA & 700-300 B.C. \\
\hline Hellenistic & HEL & 300-65 B.C. \\
\hline Roman & ROM & 65 B.C.-A.D. 300 \\
\hline Late Antique & LANT & A.D. 300-650 \\
\hline Early Medieval & EMED & A.D. 650-900 \\
\hline Medieval & MED & A.D. 900-1200 \\
\hline Late Medieval & LMED & A.D. 1200-1600 \\
\hline Ottoman/Early Modern & OTT & A.D. 1600-1800 \\
\hline Nineteenth Century & 19C & A.D. 1800-1921 \\
\hline Soviet & SOV & A.D. 1921-1991 \\
\hline Contemporary & CON & A.D. 1991-present \\
\hline
\end{tabular}


APPENDIX 3 :

Catalogue of illustrated ceramics.

\begin{tabular}{|l|l|l|l|}
\hline Feature code & Locality & Description & Chronology \\
\hline F13078 & Orgora & Artefact scatter, buried structures & HEL, ROM, MED \\
\hline F13079 & Orgora & $\begin{array}{l}\text { Structures and burials exposed in cutting of } \\
\text { terrace; artefact scatter }\end{array}$ & $\begin{array}{l}\text { EBA, LBA, EIA, LIA, } \\
\text { HEL, ROM, MED, } \\
\text { OTT }\end{array}$ \\
\hline F13081 & Zveli & $\begin{array}{l}\text { Barrows, kurgans, stone features; buried, above } \\
\text { ground and excavated structures }\end{array}$ & LBA, MED-LMED \\
\hline F13082 (SU027) & Zveli & $\begin{array}{l}\text { Artefact scatter, intensive survey field on terrac- } \\
\text { es south of Zveli }\end{array}$ & $\begin{array}{l}\text { LIA, HEL, ROM, } \\
\text { MED, LMED OTT }\end{array}$ \\
\hline F13083 (SU028) & Zveli & $\begin{array}{l}\text { Artefact scatter, intensive survey field on terrac- } \\
\text { es south of Zveli }\end{array}$ & $\begin{array}{l}\text { LANT, MED-LMED, } \\
\text { 19C }\end{array}$ \\
\hline F13084 & Kheoti & Church, monastery; standing structures & MED \\
\hline F13085 & Zveli & $\begin{array}{l}\text { Zveli Rabat, southwest side: buried features, } \\
\text { artefact scatter }\end{array}$ & EBA, MBA, LBA \\
\hline F13086 & Zveli & $\begin{array}{l}\text { Zveli Rabat: settlement, buried and standing } \\
\text { structures, artefact scatters }\end{array}$ & EBA, MED, OTT \\
\hline F13087 & Chobareti & $\begin{array}{l}\text { Verana: settlement, buried and standing struc- } \\
\text { tures }\end{array}$ & EMED-LMED \\
\hline F13088 & Chobareti & Verana Church & MED-LMED \\
\hline F13091 & Zveli & $\begin{array}{l}\text { Structures; concrete industrial and agricultural } \\
\text { buildings south of Zveli }\end{array}$ & SOV \\
\hline
\end{tabular}





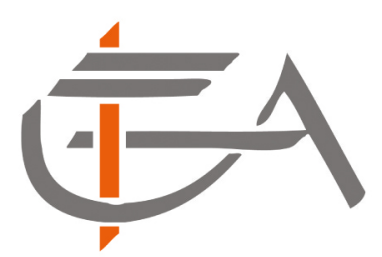

Institut Français

d'Etudes Anatoliennes

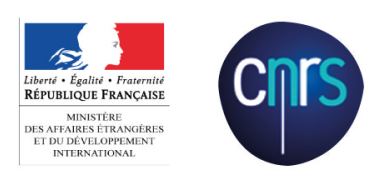

Peinture rupestre préhistorique, Sağlık Köy, près d'Alabanda, Turquie (cliché Suat Ateşlier). 